\title{
Methodiek arbeidsmarktprognoses en -indicatoren 2017-2022
}

Citation for published version (APA):

Bakens, J., Bijlsma, I., Cörvers, F., Dijksman, S., Fouarge, D., \& Poulissen, D. (2018). Methodiek arbeidsmarktprognoses en -indicatoren 2017-2022. ROA. ROA Technical Reports No. 004 https://doi.org/10.26481/umarot.2018004

Document status and date:

Published: 01/01/2018

DOI:

10.26481/umarot.2018004

Document Version:

Publisher's PDF, also known as Version of record

\section{Please check the document version of this publication:}

- A submitted manuscript is the version of the article upon submission and before peer-review. There can be important differences between the submitted version and the official published version of record.

People interested in the research are advised to contact the author for the final version of the publication, or visit the DOI to the publisher's website.

- The final author version and the galley proof are versions of the publication after peer review.

- The final published version features the final layout of the paper including the volume, issue and page numbers.

Link to publication

\footnotetext{
General rights rights.

- You may freely distribute the URL identifying the publication in the public portal. please follow below link for the End User Agreement:

www.umlib.nl/taverne-license

Take down policy

If you believe that this document breaches copyright please contact us at:

repository@maastrichtuniversity.nl

providing details and we will investigate your claim.
}

Copyright and moral rights for the publications made accessible in the public portal are retained by the authors and/or other copyright owners and it is a condition of accessing publications that users recognise and abide by the legal requirements associated with these

- Users may download and print one copy of any publication from the public portal for the purpose of private study or research.

- You may not further distribute the material or use it for any profit-making activity or commercial gain

If the publication is distributed under the terms of Article $25 \mathrm{fa}$ of the Dutch Copyright Act, indicated by the "Taverne" license above, 


\section{Maastricht University $\$ \mathrm{ROA}$}

Methodiek arbeidsmarktprognoses en -indicatoren 2017-2022

Jessie Bakens Ineke Bijlsma Frank Cörvers Sander Dijksman Didier Fouarge Davey Poulissen

\section{ROA Technical Report}

ROA-TR-2018/4

Researchcentrum voor Onderwijs en Arbeidsmarkt | ROA Research Centre for Education and the Labour Market / ROA 


\title{
Methodiek arbeidsmarktprognoses en -indicatoren 2017-2022
}

\author{
Jessie Bakens \\ Ineke Bijlsma \\ Frank Cörvers \\ Sander Dijksman \\ Didier Fouarge \\ Davey Poulissen
}

ROA-TR-2018/4

Mei 2018

Research Centre for Education and the Labour Market Maastricht University

P.O. Box 616, 6200 MD Maastricht, The Netherlands

$\mathrm{T}+31433883647 \mathrm{~F}+31433884914$

secretary-roa-sbe@maastrichtuniversity.nl www.roa.nl 


\section{Inhoud}

Voorwoord

1 Inleiding 1

2 Structuur van de gepresenteerde arbeidsmarktinformatie $\quad 2$

2.1 Relevantie van arbeidsmarktinformatie 2

2.2 Componenten van het arbeidsmarktinformatiesysteem 2

$\begin{array}{ll}2.3 & \text { Detaillering en bruikbaarheid }\end{array}$

3 De actuele situatie op de arbeidsmarkt $\quad 5$

4 Methodiek arbeidsmarktprognoses $\quad 6$
4.1 Inleiding
6
4.2 Methodiek uitbreidingsvraag $\quad 6$
4.3 Methodiek vervangingsvraag 12
4.4 Methodiek instroom van schoolverlaters op de arbeidsmarkt $\quad 17$
4.5 Baanopeningen en typering arbeidsmarktperspectieven 21
$\begin{array}{lll}4.6 & \text { Typering knelpunten in de personeelsvoorziening } & 23\end{array}$

5 De structurele arbeidsmarktsituatie $\quad 26$

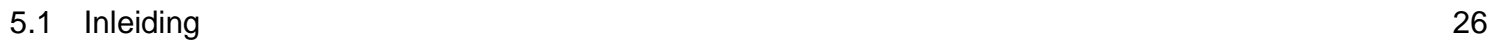

$\begin{array}{llr}5.2 \text { Conjunctuurgevoeligheid } & 26\end{array}$

$\begin{array}{llr}5.3 & \text { Uitwijk- en substitutiemogelijkheden } & 27\end{array}$

$\begin{array}{llr}5.4 & \text { Concurrentie-index } & 28\end{array}$

$\begin{array}{lr}\text { Literatuur } & 29\end{array}$

$\begin{array}{lr}\text { Appendix A } & 31\end{array}$

Appendix B. Technische toelichting op variabelen in het AIS 33 


\section{Voorwoord}

In dit werkdocument wordt de methodiek beschreven die gevolgd is bij het samenstellen van de arbeidsmarktinformatie over 21 bedrijfssectoren, 113 beroepsgroepen en 90 opleidingstypen, welke opgenomen is in het Arbeidsmarkt Informatie Systeem (AIS) van het ROA en gebruikt wordt in het rapport De arbeidsmarkt naar opleiding en beroep tot 2022 (ROA, 2017a). ${ }^{1}$ Dit rapport is in december 2017 uitgebracht in het kader van het Project Onderwijs-Arbeidsmarkt (POA) van het ROA. ${ }^{2}$

Het rapport biedt een overzicht van recente trends op Nederlandse arbeidsmarkt, alsook van de huidige en te verwachten toekomstige arbeidsmarktontwikkelingen in de periode 2017-2022. Deze informatie - die elke twee jaar wordt gegenereerd - is van belang voor zowel het geven van voorlichting aan degenen die aan een opleiding willen beginnen, als voor het nemen van beleidsbeslissingen door instanties die betrokken zijn bij de aansluiting tussen het onderwijs en de arbeidsmarkt. ${ }^{3}$ In bijlage $\mathrm{C}$ van het rapport wordt een overzicht gegeven van de beschikbare arbeidsmarktinformatie naar 21 bedrijfssectoren, 113 beroepsgroepen en 90 opleidingstypen. Deze informatie is opgenomen in het AIS waarin gebruikers zelf op eenvoudige wijze tabellen kunnen samenstellen. ${ }^{4}$ Meer informatie over het AIS is te vinden in paragraaf 2.2 van dit document.

Het POA wordt gefinancierd door het Ministerie van Onderwijs, Cultuur en Wetenschap (OCW), het Ministerie van Economische Zaken en Klimaat (EZK), het Ministerie van Binnenlandse Zaken en Koninkrijksrelaties (BZK), het Ministerie van Sociale Zaken en Werkgelegenheid (SZW), het UWV WERKbedrijf, de stichting Samenwerking Beroepsonderwijs Bedrijfsleven (SBB) en Randstad Nederland. Vanaf 2018 wordt de financiering vanuit de Ministeries gecoördineerd door het National Regieorgaan Onderwijsonderzoek (NRO; dossiernummer 405-17900).

1. Inclusief de categorieën 'overig' wordt er feitelijk gerekend met in totaal 22 bedrijfssectoren, 114 beroepsgroepen en 96 opleidingstypen.

2. Zie http://roa.sbe.maastrichtuniversity.nl/?portfolio=poa-project-onderwijs-arbeidsmarkt-2

3. Zie Fouarge (2015) voor een overzicht van het gebruik van de binnen POA ontwikkelde arbeidsmarktinformatie.

4. Zie http://roastatistics.maastrichtuniversity.nl/ 


\section{$1 \quad$ Inleiding}

Dit document dient als achtergrond informatie bij het rapport De arbeidsmarkt naar opleiding en beroep tot 2022 (ROA, 2017a) waarin de resultaten van het Project Onderwijs-Arbeidsmarkt (POA) staan beschreven. In dit werkdocument wordt verder ingegaan op de gebruikte databronnen, de definities van een aantal begrippen, en op de prognosemethodiek die wordt gebruikt in het POA. Voor een volledige beschrijving van de prognosemethodiek, een onderbouwing van de prognosemethodiek, en de uitgangspunten van het POA kunnen naast dit document verschillende andere publicaties ${ }^{5}$ en de referenties in Bijlage A van De arbeidsmarkt naar opleiding en beroep tot 2022 (ROA, 2017a) geraadpleegd worden.

Dit werkdocument is als volgt opgebouwd. In hoofdstuk 2 wordt de structuur van het AIS besproken. Vervolgens wordt in hoofdstuk 3 ingegaan op de actuele data in het AIS. In hoofdstuk 4 wordt de prognosemethodiek besproken en in hoofdstuk 5 wordt ingegaan op de indicatoren met betrekking tot de structurele kenmerken van de arbeidsmarkt.

5. Zie o.a. Borghans, De Grip en Willems (1995), Van Eijs en De Grip (1998), Borghans, De Grip en Heijke (2000), Cörvers, De Grip en Heijke (2002), Cörvers (2003) en Cörvers en Heijke (2004). 


\section{Structuur van de gepresenteerde arbeidsmarktinformatie}

\subsection{Relevantie van arbeidsmarktinformatie}

Het doel van POA is om inzicht te verschaffen in de actuele en verwachte, middellange termijn (6 jaar), situatie op de arbeidsmarkt verbijzonderd naar beroep en opleiding. Met deze arbeidsmarktinformatie kunnen betrokken partijen beter inzicht krijgen in de huidige en toekomstige ontwikkelingen met betrekking tot de aansluiting tussen onderwijs en arbeidsmarkt en zo meer adequate beslissingen nemen. Gedegen informatie over de aansluiting tussen onderwijs en arbeidsmarkt helpt de betrokkenen, zoals leerlingen, scholen, de overheid, de arbeidsvoorzieningsorganisatie, en bedrijven bij het nemen van beslissingen, waardoor de discrepanties tussen vraag en aanbod op de arbeidsmarkt kunnen verminderen. Door de verstrekte informatie kan een leerling die een studiekeuze maakt zich oriënteren op de arbeidsmarktperspectieven op het moment dat hij of zij de studie zal afronden. Onderwijsaanbieders krijgen meer inzicht in de relevantie van hun aanbod van opleidingen voor de verwachte vraag naar personeel voor de komende zes jaar (tot en met 2022). Op deze wijze kan een zo goed mogelijk beeld worden geven van de arbeidsmarktsituatie bij afstuderen van degenen die thans aan het begin van hun studie staan.

De structuur van de informatie sluit hierbij aan door voor zowel beroepen als voor opleidingen kengetallen te presenteren met betrekking tot de actuele situatie op de arbeidsmarkt en de arbeidsmarktsituatie tot 2022. Ook voor andere partijen die betrokken zijn bij het onderwijs is het van belang dat er vooruit wordt gekeken. Dit voorkomt een procyclisch beleid, dat te sterk reageert op de actuele arbeidsmarktsituatie. De perspectieven voor schoolverlaters worden weergegeven met de Indicator Toekomstige Arbeidsmarktperspectieven (ITA). Voor werkgevers en onderwijsaanbieders geven de Indicator Toekomstige Knelpunten in de Personeelsvoorziening (ITKP) en de Indicator Toekomstige Knelpunten in de Personeelsvoorziening naar Beroep (ITKB) aan voor welke opleidingstypen en beroepsgroepen wervingsproblemen te verwachten zijn.

\subsection{Componenten van het arbeidsmarktinformatiesysteem}

De arbeidsmarktinformatie die gegenereerd wordt in het kader van het POA wordt opgenomen in het Arbeidsmarkt Informatie Systeem (AIS) van het ROA. Het AIS is online te benaderen via http://roastatistics.maastrichtuniversity.nl. Het AIS van POA is opgebouwd uit drie componenten (welke verder beschreven worden in de volgende hoofdstukken) en bevat zowel een nationale als een regionale component: ${ }^{6}$

1. De informatie over de actuele situatie geeft aan hoe de huidige positie is van werkenden en schoolverlaters met een bepaalde opleidingsachtergrond.

2. Het arbeidsmarktperspectief van de verschillende opleidingstypen geeft op grond van de verwachte kwantitatieve verschuivingen in vraag en aanbod aan hoe deze positie zich tot 2022 zal ontwikkelen.

3. Ten slotte plaatsen de structurele kenmerken van de arbeidsmarkt de positie van een bepaalde opleiding of beroep in een ruimer perspectief.

De actuele informatie geeft de meest recente arbeidsmarkt gegevens weer. De gegevens gaan over het jaar 2016, of het gemiddelde van de afgelopen twee jaren (2015-2016) en zijn gebaseerd op de volgende databronnen: de Enquête Beroepsbevolking (EBB) van het Centraal Bureau voor de Statistiek (CBS), het Sociaal Statistisch bestand (SSB) van het CBS, het Schoolverlaters Informatie Systeem (SIS) van ROA, Open Data van de Dienst Uitvoering Onderwijs (DUO), Arbeidsvraag en Arbeidsaanbodpanel van het Sociaal Cultureel Planbureau (SCP), en het Programme for the International Assessment of Adult Competencies (PIAAC) van de

6. De methodiek bij de regionale arbeidsmarktinformatie en regionale prognoses is gedocumenteerd in Bakens et al. (2018). 
Organisatie voor Economische Samenwerking en Ontwikkeling (OESO). ${ }^{7}$ Zo wordt een beeld gegeven van de absolute en relatieve omvang van het totaal aantal werkenden in een beroepsgroep, de omvang van de potentiële beroepsbevolking, en het aantal werkenden met een bepaalde opleidingsachtergrond. Deze aantallen werkenden worden vervolgens ook verbijzonderd naar persoonlijke kenmerken zoals geslacht, etniciteit, en leeftijd en naar de functiekenmerken, zoals contract type, en contract omvang. Voor schoolverlaters wordt - voor de verschillende opleidingstypen - bovendien een beeld gegeven van de actuele aansluitingsproblemen op de arbeidsmarkt, zowel wat betreft het percentage werkloze schoolverlaters, als de mate waarin er sprake is van onderbenutting. Daarnaast wordt o.a. weergegeven hoeveel procent van de schoolverlaters deelneemt aan een vervolgopleiding, hoeveel procent buiten hun vakgebied werkzaam is, en hoeveel procent spijt heeft van de opleidingskeuze.

Voor het arbeidsmarktperspectief op de middellange termijn worden de verwachte baanopeningen voor zowel beroepsgroepen als voor opleidingstypen gegeven. Deze vraag naar nieuwkomers is uitgesplitst naar de uitbreidingsvraag (vraag als gevolg van banengroei) en de vervangingsvraag (vraag als gevolg van het verloop vanwege pensionering, arbeidsongeschiktheid, (tijdelijke) uittreding, beroepsmobiliteit e.d.). Voor de opleidingen wordt daarnaast ook de instroom van nieuwkomers op de arbeidsmarkt voorspeld, zodat vraag en aanbod met elkaar vergeleken kunnen worden. Op basis van deze confrontatie, en de substitutieprocessen die afhankelijk van de uitkomst op gang komen, wordt een indicator van de verwachte arbeidsmarktsituatie naar opleidingstypen opgesteld. Op vergelijkbare wijze worden ook de verwachte knelpunten in de personeelsvoorziening in kaart gebracht waarbij bovendien per bedrijfssector de opleidingstypen met de grootste knelpunten worden aangeduid. Ook voor de beroepsgroepen wordt een indicator opgesteld van de verwachte knelpunten in de personeelsvoorziening.

De structurele kenmerken van de arbeidsmarkt dienen enerzijds als verdieping van het inzicht in de huidige arbeidsmarktpositie van werkenden en schoolverlaters. Anderzijds zijn deze een aanvulling op de prognoses, omdat ze inzicht geven in mogelijke aanpassingsmechanismes die de discrepantie tussen vraag en aanbod kunnen terugdringen. Op die manier fungeren de indicatoren van de structurele kenmerken ook als risicoindicatoren. Zo geeft de concurrentie-index aan hoe sterk de beroepenstructuur van twee opleidingen op elkaar lijkt, en daarmee hoe groot de kans is dat personen met een verschillende opleidingsachtergrond in dezelfde beroepsgroep werkzaam zijn. Daarnaast wordt weergegeven in hoeverre een beroep, c.q. opleiding, afhankelijk is van de ontwikkeling in een enkele bedrijfssector of beroepsgroep en in welke mate de werkgelegenheid (naar sector) gevoelig is voor de conjuncturele ontwikkelingen.

Binnen het AIS worden de actuele data, de prognoses, en de structurele kenmerken telkens op kwalitatieve wijze getypeerd. Met uitzondering van de indicatoren voor de toekomstige arbeidsmarktsituatie wordt hierdoor aangegeven wat op het desbetreffende punt de relatieve positie van het beroep of de opleiding is ten opzichte van de andere beroepen of opleidingen. Doorgaans vinden de typeringen plaats op basis van een vijf-puntsschaal, lopend van erg hoog, hoog, gemiddeld, laag, tot erg laag. ${ }^{8}$ De kwalitatieve typering zorgt ervoor dat de cijfers eenvoudiger zijn te interpreteren en dat schijnnauwkeurigheden worden vermeden. Daarbij wordt tevens enigszins van deze procedure afgeweken door de berekende grenzen tussen de typeringsintervallen af te ronden. In appendix A van dit werkdocument wordt voor kernvariabelen uit het AIS aangegeven welke grenzen zijn gehanteerd bij de kwalitatieve typering.

7. Informatie over vaardigheden uit PIAAC en de arbeidsomstandigheden per sector (SCP Arbeidsaanbodpanel) hebben betrekking op 2014. De gegevens over werkenden en schoolverlaters in het AIS worden jaarlijks geactualiseerd, in tegenstelling tot de prognosegegevens die tweejaarlijks worden geactualiseerd. Dit betekent dat de gegevens over werkenden (gemiddelde voor de jaren 2015-2016) en schoolverlaters (2016) in de loop van 2016 worden geactualiseerd.

8. De typeringen zijn gebaseerd op de methodiek beschreven in Wieling, De Grip en Willems (1990). 


\subsection{Detaillering en bruikbaarheid}

Voor gebruikers van de arbeidsmarktinformatie is het doorgaans wenselijk om de informatie over beroepen en de opleidingen op een zo gedetailleerd mogelijk niveau te geven. De onzekerheidsmarges waarmee de EBB-cijfers zijn omgeven leggen echter een ondergrens op aan de mate van detaillering die in het informatiesysteem voor beroepen en opleidingen kan worden toegepast. Voor de EBB-gegevens geldt een ondergrens voor de aantallen personen die in de tabellen gepubliceerd mogen worden. Voor jaarcijfers wordt een minimum van 80 (ongewogen) respondenten gehanteerd. Waar deze ondergrens niet werd bereikt wordt in de overzichtstabellen het betreffende getal met een '--' aangegeven. Voor de gegevens uit het SIS (de schoolverlatersenquêtes BVEMonitor, HBO-Monitor, en WO-Monitor) ${ }^{9}$, en uit PIAAC geldt een ondergrens voor publicatie van 20 respondenten.

Voor de bruikbaarheid van de prognoses, actuele informatie, en structurele arbeidsmarkt indicatoren is het van belang dat de gehanteerde opleidings- en beroepsindeling zo goed mogelijk aansluit bij het Nederlandse opleidingssysteem en de Nederlandse arbeidsmarkt. Ten opzichte van de vorige prognoses (ROA 2013, 2015a) wordt er nu gewerkt met een nieuwe indeling van beroepen en opleidingen (zie bijlage $B$ in ROA, 2017). Dit is noodzakelijk vanwege het door CBS uitgevoerde herontwerp van de EBB. Vanaf 2013 wordt in de EBB het beroep van werkenden gecodeerd naar de ISCO classificatie en de opleidingen naar de ISCED classificatie. Samen met het CBS heeft ROA een beroepenindeling afgeleid van de ISCO (ROA 2015c). Tevens heeft ROA een indeling van opleidingen afgeleid van de ISCED 2007, waarbij een onderscheid gemaakt wordt naar niveaus binnen het mbo (ROA 2016).

Vanwege het toenemende belang van regionale arbeidsmarktinformatie wordt een deel van de beschikbare landelijke arbeidsmarktinformatie en -prognoses gedifferentieerd naar 35 regio's. Het gaat hierbij om gegevens over de werkgelegenheid naar 21 bedrijfssectoren en 16 opleidingscategorieën van het mbo, hbo en wo, waarbij er binnen het mbo een onderscheid wordt gemaakt tussen mbo niveau $2 / 3$ enerzijds, en mbo niveau 4 anderzijds. Tevens zijn er regionale prognoses voor de uitbreidingsvraag, vervangingsvraag, arbeidsmarktinstroom, en de discrepantie-indicator (ITA) samengesteld. De gegevens voor mbo en hbo zijn gedifferentieerd naar richting, voor het wo is het totaal over alle richtingen berekend. De methodiek voor de regionale prognoses is verder uitgelegd in Cörvers et al. (2018). 


\section{De actuele situatie op de arbeidsmarkt}

In dit hoofdstuk wordt een overzicht gegeven van de gegevens in het informatiesysteem met betrekking tot de actuele arbeidsmarktpositie vanuit de invalshoek van bedrijfssectoren, beroepsgroepen, en opleidingstypen. De meeste gegevens die betrekking hebben op de gehele werkzame beroepsbevolking zijn gebaseerd op de EBB. De gegevens hebben betrekking op het gemiddelde aantal werkenden in de jaren 2015 en 2016. Daarnaast wordt ook informatie gegeven vanuit andere databronnen: het SSB, het Arbeidsvraag en Arbeidsaanbodpanel, en PIAAC. Door een koppeling van de EBB en het SSB wordt informatie over lonen naar beroep en opleiding gegeven in het AIS. De looninformatie heeft betrekking op 2015. Daarnaast bevat het AIS PIAAC-data die inzicht geven in vier kernvaardigheden op het werk. Ook de data uit het Arbeidsvraag en Arbeidsaanbodpanel, bestaande uit zowel vacature-informatie als informatie over het type werk dat men per sector verricht, hebben betrekking op de gehele werkzame bevolking.

Naast de informatie over de actuele arbeidsmarktpositie van de werkzame beroepsbevolking naar opleiding, beroep en/of sector, wordt er aanvullende informatie gegeven over de positie van schoolverlaters. Deze schoolverlatersinformatie is allereerst gebaseerd op de schoolverlatersenquêtes (VO-monitor, BVE-monitor en de HBO-Monitor), welke geïntegreerd zijn in het SIS van het ROA. Voor het avo, vbo, en mbo is gebruik gemaakt van de BVE-monitor 2016, terwijl de gegevens over het hbo gebaseerd zijn op de HBO-Monitor 2016 (zie ook $\mathrm{ROA}, \quad 2017 \mathrm{~b}$ en http://roa.sbe.maastrichtuniversity.nl/?portfolio=school-leaver-surveys). In deze schoolverlatersenquêtes zijn in het najaar van 2016 schoolverlaters en afgestudeerden geënquêteerd ongeveer anderhalf jaar na het voltooien van hun opleiding (schooljaar 2014/2015). Daarnaast wordt gebruik gemaakt van de WO-monitor. De WO-gegevens hebben betrekking op 2015, het laatst beschikbare jaar bij het opstellen van het AIS. Hierdoor bevat het AIS schoolverlaterinformatie over de volle breedte van het onderwijsstelsel.

Als laatste bevat het AIS ook informatie over leerlingen en gediplomeerden via DUO. Het betreft zowel het aantal leerlingen/gediplomeerden als ook het percentage vrouw, BBL en deeltijd/duaal. De trendmatige ontwikkeling wordt niet in AIS opgenomen vanwege het herontwerp van de EBB in 2013 (zie hoofdstuk 4).

In Appendix B is een tabel opgenomen met de definities van de variabelen met betrekking tot de actuele arbeidsmarktsituatie. De variabelen zijn gesorteerd naar de bron waar de gegevens uit afkomstig zijn. 


\section{Methodiek arbeidsmarktprognoses}

\subsection{Inleiding}

In dit hoofdstuk wordt ingegaan op de gehanteerde onderzoeksmethoden van de middellangetermijnprognoses naar beroepsgroep en opleidingstype voor de periode 2017-2022. In de inleiding 'Doel en opzet van de arbeidsmarktprognoses' van De arbeidsmarkt naar opleiding en beroep tot 2022 (ROA, 2017a) wordt een globaal overzicht gegeven van het prognosemodel van het informatiesysteem. In dit hoofdstuk wordt meer specifiek op de verschillende prognose-onderdelen ingegaan. Achtereenvolgens zal de methodiek van de prognose van de uitbreidingsvraag, de prognose van de vervangingsvraag, en de prognose van de toekomstige instroom van nieuwkomers op de arbeidsmarkt worden besproken. Ten slotte wordt een toelichting gegeven op de totstandkoming van de samenvattende indicatoren van de arbeidsmarktperspectieven per opleidingstype (incl. bespreking van baanopeningen), en de verwachte knelpunten in de personeelsvoorziening per opleidingstype en per beroepsgroep. In Tabel B1 in bijlage B is de technische toelichting op de variabelen systematisch weergegeven.

\footnotetext{
Veranderingen in EBB data

Een van de databronnen die in de prognoses wordt gebruikt is de EBB van het CBS. In 2013 is er een revisie geweest in de vragenlijst van de EBB, waardoor er een trendbreuk is ontstaan. In dit rapport wordt daarom per vraagcomponent aangegeven hoe er met deze breuk is omgegaan.
}

Daarnaast heeft de revisie tot veranderingen in de meting van het beroep geleid (ROA, 2015c), alsook in de meting van opleidingsniveau en richting (ROA, 2016).

Daarnaast hanteert ROA (net als het CBS, het CPB en het UWV) met ingang van 2015 de internationale ILOdefinitie voor het meten van de omvang van de beroepsbevolking. Deze definitie wijkt op een aantal punten sterk af van de gebruikelijke Nederlandse definitie van de beroepsbevolking. Een belangrijk verschil is dat in de oude definitie een urencriterium van minimaal 12 uur betaald werk per week gold, terwijl deze grens in de nieuwe definitie op 1 uur betaald werk ligt. Voor veranderingen in de omvang en samenstelling van de beroepsbevolking die optreden als gevolg van de nieuwe definitie van de beroepsbevolking, wordt verwezen naar Bijlsma et al. (2015b). In de prognosemethodiek van het ROA heeft de overgang op de ILO-definitie voornamelijk gevolgen voor de vervangingsvraag. Op deze gevolgen zal bij de bespreking van de vervangingsvraag in paragraaf 4.3 uitgebreid worden ingegaan.

\subsection{Methodiek uitbreidingsvraag}

Voor het samenstellen van de ROA arbeidsmarktprognoses is gebruik gemaakt van ramingen uit het Centraal Economisch Plan 2017 (CPB, 2017a). Dit waren de meest recent beschikbare CPB-ramingen bij de start van het project. Voor 2017 en 2018 wordt in deze ramingen rekening gehouden met een economische groei van, respectievelijk, 2,1\% en 1,8\%. Voor de periode 2017-2022 wordt rekening gehouden met een structurele groei van $1,7 \%$. Door gebruik te maken van de CPB-ramingen sluiten de ROA-prognoses aan bij de door de Nederlandse overheid gehanteerde uitgangspunten voor economische groei en overheidsplanning. Dezelfde uitgangspunten worden ook door het UWV gehanteerd voor het opstellen van hun arbeidsmarktprognoses (UWV, 2017).

Twee ontwikkelingen hebben zich in de nazomer 2017 voorgedaan die van invloed zijn op de vraag naar arbeid. Ten eerste is eind september 2017 duidelijk geworden dat er 2,1 miljard euro extra vrijkomt voor de verpleeghuizen in de komende kabinetsperiode. CPB rekende uit dat er hiermee 40.000 extra voltijdsbanen bijkomen, vooral voor verplegende en verzorgende functies. De impact hiervan hebben wij kunnen doorrekenen in de vraagprognoses door de vraag naar verplegende en verzorgende functies met 54.000 extra personen te 
verhogen (40.000 voltijds banen maal een deeltijdfactor van 1,35 voor de zorgsector). Deze extra werkgelegenheid is vervolgens verdeeld over de onderliggende verplegende en verzorgende. Verdeling vond plaats naar rato van de uitbreidingsvraag in deze functies. ${ }^{10}$

Ten tweede schetst de in oktober 2017 verschenen Actualisatie Middellangetermijn Verkenning 2018-2021 (CPB, 2017b), waarin ook het recente regeerakkoord is verwerkt, nog betere perspectieven voor de korte termijn economische groei, maar aangezien deze ramingen nog niet beschikbaar waren bij de start van het project kon deze actualisatie nog niet meegenomen worden. In 2018 publiceert ROA een update van de uitbreidingsvraag met de meest recent beschikbare middellange termijn groeiramingen van het CPB.

Figuur 4.1

Overzicht van de totstandkoming van de prognoses van de uitbreidingsvraag naar beroep en opleiding

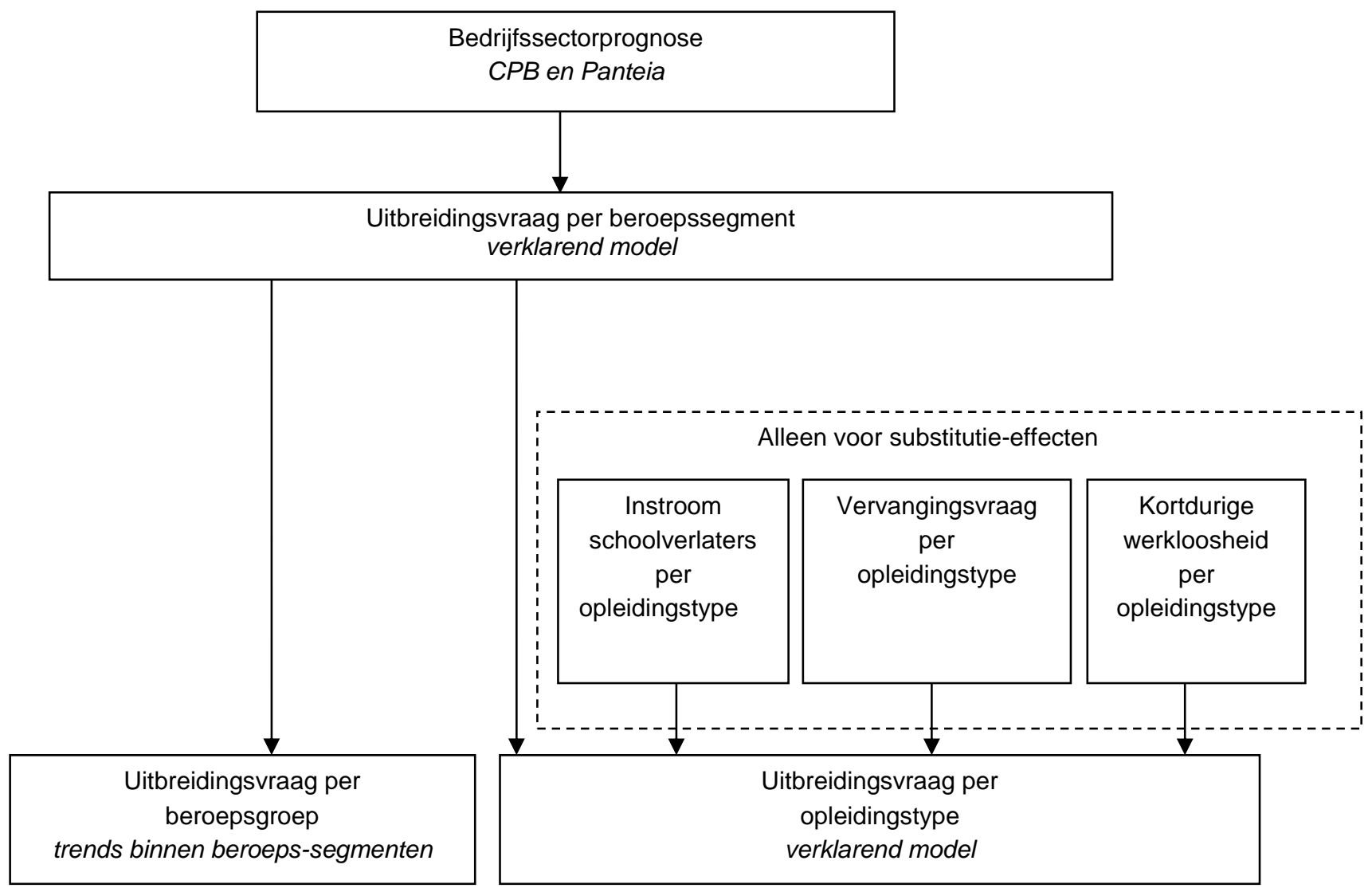

De macro-economische en sectorprognoses van het CPB zijn door Panteia op verzoek van het ROA gedifferentieerd naar 21 verschillende bedrijfssectoren (exclusief de sector 'onbekend'). Voor deze differentiatie is gebruik gemaakt van verdeelmodellen Bij het samenstellen van de sectorprognoses van maakt Panteia gebruik van het zogenaamde PRISMA-M model (Kwaak, 2006). De sectordifferentiatie is hierbij gebaseerd op de Athena-indeling van het CPB (zie bijvoorbeeld CPB, 1990, 2005 \& 2006). Voor de toepassing van dit verdeelmodel is dus uitgegaan van het macro-economische kader van het CPB. Het betreft hier niet alleen de

10. Aan de beroepenkant van het model betreft het: verpleegkundigen (mbo), verzorgenden en gespecialiseerde verpleegkundigen.Aan de opleidingenkant van het model betreft het: mbo 2/3 gezondheidszorg, mbo 4 gezondheidszorg en hbo verpleegkunde en medische diagnostiek). 
prognoses voor de werkgelegenheid, maar ook voor de toegevoegde waarde, de investeringen in kapitaal en de P/A-ratio (de personen versus arbeidsjaren). De arbeidsvolume-prognoses van het CPB zijn met behulp van prognoses van de P/A-ratio's van het CPB en Panteia omgerekend naar werkzame personen. Voor de berekening van de toekomstige ontwikkelingen wordt uitgegaan van het geschatte aantal werkenden in het basisjaar 2016.

\section{Het beroepenmodel}

In aansluiting op de prognoses van de uitbreidingsvraag voor bedrijfssectoren, worden door het ROA prognoses gemaakt van de verschuivingen in de beroepenstructuur binnen de onderscheiden bedrijfssectoren (zie figuur 4.1). Hierdoor kan er rekening gehouden worden met het feit dat binnen een bedrijfssector bepaalde beroepsgroepen zich sneller ontwikkelen dan andere. Voorts zijn er in het zogenaamde beroepenmodel van de uitbreidingsvraag, naast de trend van de werkgelegenheid, verschillende verklarende variabelen gebruikt om de prognoses van de uitbreidingsvraag naar beroep samen te stellen.

In figuur 4.1 staat aangegeven hoe de prognoses van de werkgelegenheidsontwikkeling voor beroepen en opleidingen tot stand komen. Vanuit de bedrijfssectorprognoses wordt een prognose opgesteld voor beroepssegmenten. Vervolgens vindt er vanuit de werkgelegenheidsprognoses per beroepssegment een verdere uitsplitsing plaats naar de beroepsgroepen. De gebruikte beroepenindeling, de Beroepenindeling ROA-CBS 2014, is gebaseerd op de International Standard Classification of Occupations (ISCO) 2008. Er worden in totaal 41 beroepssegmenten en 114 beroepsgroepen onderscheiden (beide inclusief categorie 'overig'). ${ }^{11}$

De prognoses van de werkgelegenheidsontwikkelingen per beroepssegment vormen de basis voor de prognoses van de uitbreidingsvraag per opleidingstype. In het opleidingenmodel vindt een confrontatie plaats tussen vraag en aanbod, waardoor ook de invloeden op de vraag die veroorzaakt worden door overschotten of tekorten in aanverwante studierichtingen in het model kunnen worden opgenomen. Hiervoor zijn de prognoses van de arbeidsmarktinstroom van schoolverlaters, de vervangingsvraag en de informatie over de kortdurige werkloosheid per opleidingstype aan het begin van de prognoseperiode noodzakelijke invoergegevens voor het model.

In het beroepenmodel wordt de voorspelde werkgelegenheidsontwikkeling per bedrijfstak gebruikt als input voor de werkgelegenheidsontwikkeling per beroepssegment en beroepsgroep. Hierbij wordt de veronderstelling gemaakt dat de werkgelegenheid per beroepsgroep volledig door de vraagzijde van de markt bepaald wordt. Om meer stabiliteit te verkrijgen in de schattingen voor de beroepsgroepen is er besloten om enkele beroepssegmenten samen te voegen met verwante beroepssegmenten. ${ }^{12}$ De ontwikkelingen in de vraag per beroepssegment worden bepaald door de werkgelegenheidsverschuivingen tussen bedrijfssectoren en de veranderingen in de beroepenstructuur van de werkgelegenheid per bedrijfssector.

De uitbreidingsvraag naar beroep is geschat met EBB-data van 1996 tot en met 2016. Het gaat bij deze werkgelegenheidscijfers om werkzame personen die voor minstens 1 uur per week betaald werk hebben. In de EBB-matrices van 41 beroepssegmenten naar 21 bedrijfssectoren zijn de aantallen lager dan de door het CBS vereiste ondergrens gelijkgesteld aan 0 . Hierdoor verdwijnen in iedere bedrijfssector een aantal kleinere beroepssegmenten. Beroepssegmenten die voor één of meerdere jaren niet voorkomen in de tijdreeks zijn weggelaten.

Herontwerp van de EBB door het CBS heeft trendbreuken voor enkele tijdreeksen met zich meegebracht. In het eerste deel van het door ons gebruikte beroepenmodel, dat wil zeggen bij de schatting van de uitbreidingsvraag naar beroepssegment op basis van de sectorprognoses, is deze breuk opgevangen middels de opname van

11. Voor meer informatie over de Beroepenindeling zie ROA (2017a) en paragraaf 2.3 van dit technisch rapport.

12. Het gaat hierbij om de volgende samenvoegingen van beroepssegmenten: "Vakspecialisten ICT" zijn samengevoegd met

"Specialisten ICT", "Vakspecialisten gezondheidszorg" zijn samengevoegd met "Artsen, therapeuten en gespecialiseerd verpleegkundigen", en "Ingenieurs en onderzoekers" met "Vakspecialisten natuur en techniek". Ook zijn de beroepsgroepen "Productiemachinebedieners" met "Assemblagemedewerkers" samengevoegd. 
dummyvariabelen. Voor elk jaar in de periode 1996-2016 is een aparte dummyvariabele opgenomen. De veronderstelling hierachter is dat de trendmatige ontwikkelingen in het aantal werkenden naar beroep en opleiding vóór en ná de trendbreuk niet van elkaar verschillen, en dat er slechts sprake is van een verschil in de verdeling van het aantal werkenden tussen de beroepen en tussen de opleidingen. De trendbreuk die ontstaat door het herontwerp van de EBB zal in dit geval worden opgevangen door de dummyvariabelen.

De beroepenstructuur binnen bedrijfssectoren wordt geschat aan de hand van het model dat ontwikkeld is door Cörvers en Dupuy (2010). ${ }^{13}$ In dit model spelen, behalve de tijdtrend, twee factoren een rol bij de verklaring van de veranderingen in de vraag naar beroepen binnen bedrijfssectoren. De beroepenstructuur binnen bedrijfssectoren wordt bepaald door twee variabelen: (1) het productieniveau, oftewel de toegevoegde waarde per bedrijfssector en (2) de kapitaalintensiteit, oftewel de kapitaalgoederenvoorraad, per bedrijfssector. ${ }^{14}$ Bovendien wordt in het model rekening gehouden met de invloed van schokken in de economie en de invloed van werkgelegenheid in een bepaalde sector op de werkgelegenheid in andere sectoren, inclusief de beroepenstructuur in deze sectoren. ${ }^{15}$

Om het model te schatten zijn voor de 21 verschillende bedrijfssectoren data verzameld over de toegevoegde waarde en de investeringen in kapitaal tussen 1996 en 2016. De data voor toegevoegde waarde en investeringen in kapitaal zijn gebaseerd op de Nationale Rekeningen van het CBS. De investeringen in kapitaal zijn omgerekend naar voorraadgrootheden volgens de algemeen gebruikte Perpetual Inventory Method (PIM). De gehanteerde afschrijvingspercentages zijn $10 \%$.

Het volgende log-log model voor de werkgelegenheid in beroepssegment $j$ per bedrijfssector $i$ wordt geschat:

$$
\begin{gathered}
l_{i j t}=\alpha_{i j}+\beta_{i j} d_{t}+x_{i t}^{\prime} \delta_{i j}+\varepsilon_{i j t} \\
\Delta x_{i t}=\xi_{i t} \\
\xi_{i t}=\sum_{o s} \gamma_{o s}^{i} \varepsilon_{o s t-1}+\sum_{s} \Gamma_{s}^{i} \xi_{s t-1} \\
\varepsilon_{i j t}=\sum_{o s} \eta_{o s}^{i j} \varepsilon_{o s t-1}+\sum_{s} \xi_{s t-1}^{\prime} \theta_{s}^{i j}
\end{gathered}
$$

waarbij de werkgelegenheid van beroepssegment $\mathrm{j}$ in bedrijfssector $\mathrm{i}$ en jaar $\mathrm{t}$ is weergegeven door $l_{i j t}$, en waarbij $i \in\{1, \ldots, 21\}, j \in\{1, \ldots, 41\}, t \in\{1996, \ldots, 2022\}$. De beroepen en de sectoren worden respectievelijk weergeven door $o$ en $s$. Verder is $x_{i t}$ een 2 bij 1 vector met de verklarende variabelen bruto toegevoegde waarde tegen markprijzen, en de kapitaalgoederenvoorraad per sector, is $d_{t}$ een tijdsdummy voor elk jaar uit de periode 1996-2016, en is $\varepsilon_{i j t}$ een storingsterm die specifiek is voor elk(e) beroepssegment en sector (zie Cörvers en Dupuy, 2010). Vergelijking 4.1 geeft de lange termijn relatie weer tussen werkgelegenheid en de trend en de verklarende variabelen, terwijl de vergelijkingen in 4.2 de korte termijn dynamiek beschrijven, oftewel de afwijkingen van het langetermijnevenwicht (de 'error correction'). In de storingstermen van de bovenstaande specificatie is rekening gehouden met intertemporele correlaties tussen combinaties van bedrijfssectoren en beroepssegmenten. Deze techniek staat bekend als de zogenaamde Dynamic OLS (Mark et al., 2005). Bovendien zijn de verschillende schattingsvergelijkingen samengevoegd, waarbij dummies voor de sectoren en

13. Het oude model was gebaseerd op Borghans en Heijke (1994). Zij gebruikten een random-coëfficiënten-model met verklarende variabelen uit het Athena-model. Zij deden de aanbeveling om nader onderzoek te verrichten naar variabelen waarmee de werkgelegenheidsontwikkeling naar beroep beter verklaard en voorspeld kan worden.

14. In een eerdere versie van het model werd ook rekening gehouden met de R\&D intensiteit in bedrijfssectoren. Deze data zijn sinds een aantal jaren echter niet meer beschikbaar.

15. Werkgelegenheidsschokken in andere sectoren dan de betreffende sector-beroep-combinaties blijken in de periode 1988$200320 \%$ van de variantie in de voorspelde werkgelegenheidsontwikkeling naar beroep te verklaren (Cörvers en Dupuy, 2010). 
de beroepssegmenten zijn opgenomen. Dit laatste verlaagt de variantie van de geschatte parameters doordat het aantal vrijheidsgraden aanzienlijk toeneemt (zie verder Cörvers en Dupuy, 2006, 2007, 2010). De prognoses voor de twee verklarende variabelen in het beroepenmodel zijn afkomstig van doorberekeningen door Panteia.

De aggregatie over dezelfde beroepssegmenten binnen de verschillende bedrijfssectoren resulteert in de prognoses van de uitbreidingsvraag per beroepssegment. Vervolgens zijn de prognoses per beroepssegment in een vervolgstap verbijzonderd naar beroepsgroepen. Hierbij is gebruik gemaakt van Swamy's randomcoëfficiënten-model (Swamy, 1970). De werkgelegenheidsgroei per beroepsgroep wordt daarbij geschat als afwijking van de totale groei van het beroepssegment waar de betreffende beroepsgroep onder valt. Om stabiele parameterschattingen te krijgen zonder daarbij de specificiteit van de afzonderlijke beroepen aan te tasten is gebruik gemaakt van een random-coëfficiënten-model. ${ }^{16}$ In dit random-coëfficiënten-model worden de waarden van de parameters bepaald als een gewogen gemiddelde van de volgende schattingen: een gemiddelde parameterwaarde over alle beroepen in het beroepssegment, en de schattingen voor de afzonderlijke beroepsgroepen. Het gewicht wordt bepaald door de nauwkeurigheid van beide onderdelen. Als er veel variatie is tussen de verschillende beroepsgroepen binnen een beroepssegment is een gepoolde schatting relatief onnauwkeurig en komt er meer gewicht op de afzonderlijke schattingen te liggen. Als deze afzonderlijke schattingen echter een hoge standaardfout hebben wordt hun gewicht verlaagd. Op deze wijze ontstaat er een optimale combinatie van de informatie van de gepoolde gegevens en de afzonderlijke schattingen:

$$
\Delta l_{t}^{g}=\Delta l_{t}^{o}+\beta_{0}^{g}+\beta_{1}^{g}\left(\Delta l_{t-1}^{g}-\Delta l_{t-1}^{o}\right)+\varepsilon_{t}
$$

waarbij:

$\Delta l_{t}^{g}=$ verandering van het aantal werkzame personen (d.w.z. de uitbreidingsvraag) in beroepsgroep $g$ tussen tijdstip $t$ en $t$ - 1 (in log);

$\Delta l_{t}^{o}=$ verandering van het totaal aantal werkzame personen in beroepssegment $o$ waartoe beroepsgroep $g$ wordt gerekend tussen tijdstip $t$ en $t$ - 1 (in log);

$\beta_{0}^{g} \quad=$ random effect voor beroepsgroep $g$;

$\beta_{1}^{g} \quad=$ random elasticity voor beroepsgroep $\mathrm{g}$.

Als we $\Delta l_{t}^{o}$ naar de linkerzijde van vergelijking 4.3 halen en deze linkerzijde herschrijven als $y_{t}^{o g}=\Delta l_{t}^{g}-\Delta l_{t}^{o}$ resulteert dit in de onderstaande vergelijking die gebruikt is om de uitbreidingsvraag naar beroepsgroep te schatten.

$$
y_{t}^{o g}=\beta_{0}^{g}+\beta_{1}^{g} y_{t-1}^{o g}+\varepsilon_{t}
$$

Bij de schattingen van het random-coëfficiënten-model is gebruik gemaakt van EBB-tijdreeksen van het aantal werkenden per beroepsgroep voor de jaren 1996-2016.

Er zijn voor deze prognoseronde enkele aanpassingen gedaan aan het hierboven beschreven model. Dit in verband met het eerder genoemde herontwerp van de EBB in 2013. Naast de eerder genoemde samenvoeging van bepaalde beroepssegmenten en beroepsgroepen nemen we in het random-coëfficiënten-model een dummy voor het breukjaar 2013 mee voor enkele beroepssegmenten. Door het gebruik van deze dummy zijn we beter in staat de trendbreuk op te vangen. Voor een aantal segmenten werkte het opnemen van deze dummy echter averechts door de structuur van de onderliggende beroepen. Daarom is de dummy voor de betreffende segmenten niet meegenomen. ${ }^{17}$

16. Borghans en Heijke (1994) geven een uitvoerige beschrijving van dit model.

17. Voor de volgende beroepssegmenten is de trendbreukcorrectie niet doorgevoerd: "Docenten", "Sportinstructeurs", "Leidsters kinderopvang en onderwijsassistenten", "Auteurs en kunstenaars", "Vakspecialisten op artistiek en cultureel gebied", "Managers horeca, detailhandel en overige diensten", "Overheidsambtenaren en -bestuurders", "Bouwarbeiders" en "Specialisten op maatschappelijk gebied". 
Bij de prognoses die in 1993 werden opgesteld is voor het eerst expliciet een onderscheid gemaakt tussen de vraag en de werkgelegenheid per opleidingstype. Onder vraag wordt verstaan de hoeveelheid werk die wordt aangeboden als de verhoudingen tussen vraag en aanbod op de arbeidsmarkt niet veranderen. Als er echter voor een bepaalde opleidingsrichting discrepanties ontstaan tussen de vraag- en aanbodontwikkeling, zullen er in de praktijk veelal aanpassingsprocessen ontstaan. Zo leidt een overschot aan de aanbodkant er mogelijk toe dat schoolverlaters banen krijgen waarin ze voorheen niet werkzaam waren. De uiteindelijke hoeveelheid werk wordt aangeduid als werkgelegenheid. Er ontstaat derhalve een verschil tussen het ex ante vraagbegrip en de ex post werkgelegenheid.

Om de te verwachten spanning tussen vraag en aanbod in kaart te brengen is de ex ante vraag het meest geschikt. De aanpassingen die achteraf plaatsvinden zijn immers al een uiting van deze spanningen tussen vraag en aanbod. In de data wordt echter de ex post vraag waargenomen. Door in het opleidingenmodel de historische vraag te baseren op deze feitelijke werkgelegenheid worden mogelijk vraag- en aanbodelementen samengenomen. Wanneer in het verleden een toename in de werkgelegenheid het gevolg was van een vergroot aanbod kan dit geïnterpreteerd worden als een toename van de ex ante vraag, waardoor de spanning tussen vraag en aanbod onderschat zal worden. Om deze verwarring tussen vraag- en aanbodelementen te voorkomen is door Borghans en Heijke (1996) een model ontwikkeld waarin het onderscheid tussen ex ante en ex post vraag naar arbeid expliciet is opgenomen. In dit model wordt, om deze twee afzonderlijke categorieën te kunnen identificeren, rekening gehouden met de onderlinge substitutie tussen opleidingstypen. In Borghans (1996) is dit model verder uitgewerkt.

\section{Figuur 4.2}

De opbouw van de vraag naar arbeid per opleidingstype

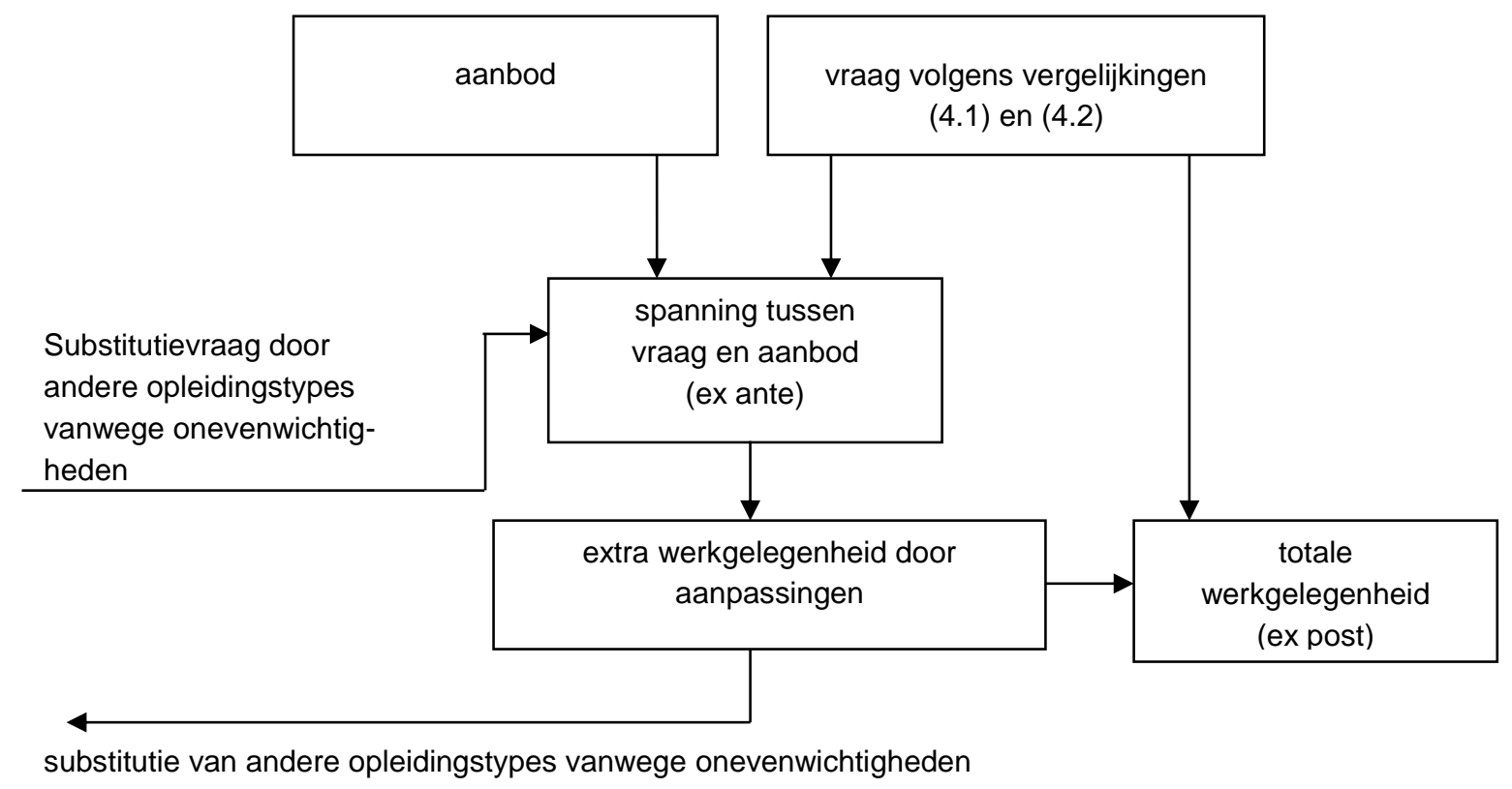

In figuur 4.2 wordt de opbouw van het model getoond. De ex ante vraag per opleidingstype (o) per beroepssegment $(b)$ wordt bepaald door de verdeling van de opleidingstypen in dit beroepssegment in het laatste observatiejaar. Op basis van Borghans (1996) en Dupuy (2006) is geschat in welke mate de vraag naar een bepaald opleidingstype toe- of afneemt als gevolg van trendmatige verschuivingen. De prognoses zijn gebaseerd op de periode 1996-2012. Idealiter zouden ook de meest recente jaren meegenomen worden, maar door de trendbreuk was dit niet mogelijk. Deze veranderingen in de vraag weerspiegelen de up- en downgradingsprocessen in de werkgelegenheidsstructuur. 
Ten slotte worden deze trendmatige ontwikkelingen gecorrigeerd voor een toe- of afname in de werkgelegenheid die het gevolg is van overschotten of tekorten aan mensen met een bepaalde opleidingsachtergrond. Als de vraag groter is dan het aanbod voor een bepaald opleidingstype zal immers de uiteindelijke werkgelegenheid zoals die wordt waargenomen kleiner zijn dan de oorspronkelijke vraag. Omgekeerd zal bij een aanbodoverschot de uiteindelijke werkgelegenheid juist groter worden vanwege verdringingsprocessen. Borghans en Willems (1998) gaan in op deze relatie tussen vraag en werkgelegenheid. Als het aanbod van een opleidingstype groter is dan de vraag, zal volgens dit model de arbeidsmarktpositie van het opleidingstype verslechteren. De nieuwkomers op de arbeidsmarkt zullen daardoor moeten uitwijken naar andere minder aantrekkelijke banen. Deze uitwijk naar andere banen is geschat op basis van de methode in Borghans (1996), met een restrictie van substitutiemogelijkheden op basis van de concurrentieindex. ${ }^{18}$ Omdat de totale vraag per beroepssegment verondersteld wordt constant te zijn, betekent de instroom van het ene opleidingstype automatisch de verdringing van andere opleidingstypen. Hier wordt verondersteld dat deze uitstroom proportioneel is aan de opleidingsstructuur van dit beroepssegment. Deze verdringing betekent voor de betreffende opleidingstypes echter een vergroting van de discrepantie tussen vraag en aanbod. Door middel van iteraties wordt een evenwichtssituatie gevonden die de ex ante vraag met substitutie aangeeft.

Deze uitbreidingsvraag met substitutie geeft aan hoe groot de vraag naar schoolverlaters met een bepaalde opleidingsachtergrond is, als er geen rekening wordt gehouden met de mate waarin dit opleidingstype zich aanpast aan de arbeidsmarktsituatie (de 'actieve substitutie'), maar waarbij wel rekening is gehouden met de vraagtoename, als gevolg van een vraagoverschot bij een andere verwante opleiding, of een vraagafname vanwege de verdringing door andere opleidingstypen (de 'passieve substitutie'). De reden waarom er geen rekening wordt gehouden met de 'actieve' substitutie is dat deze aanpassingen - in het geval van een aanbodoverschot - op zichzelf reeds een verslechtering zullen betekenen. Door de werkgelegenheid die door het aanpassingsproces op de arbeidsmarkt wordt verkregen in mindering te brengen op het aanbodoverschot zou een verslechterend perspectief onderschat worden. Het verlies aan werkgelegenheid door de aanpassingen van andere opleidingstypen betekent echter een verslechtering van de werkgelegenheid, zodat deze component wel moet worden meegenomen in de ex ante vraag (zie De Grip, Borghans en Smits, 1998 en Cörvers en Heijke, 2004).

\subsection{Methodiek vervangingsvraag}

Naast de uitbreidingsvraag is ook de vervangingsvraag een belangrijke component van het totaal aantal baanopeningen voor de nieuwkomers op de arbeidsmarkt. Met de vervangingsvraag wordt de vraag naar nieuwkomers bedoeld die ontstaat als gevolg van het verloop vanwege (vervroegde) pensionering, arbeidsongeschiktheid, (tijdelijke) uittreding (van bijvoorbeeld vrouwen, in verband met zorgtaken), beroepsmobiliteit e.d. (zie ook Willems en De Grip, 1993). Bij een toename van de werkgelegenheid is de vervangingsvraag gelijk aan het aantal werkenden dat hun baan in een bepaalde periode verlaat. De opengevallen arbeidsplaatsen zullen immers eerst moeten worden opgevuld voordat er sprake kan zijn van werkgelegenheidsgroei. Echter, ook bij een dalende werkgelegenheid kan de vraag naar nieuwkomers, uitsluitend als gevolg van de vervangingsvraag, nog aanzienlijk zijn. Het blijkt dat werkgevers voor het realiseren van een afname van het personeelsbestand bij een teruglopende vraag naar arbeid aan de 'exit'-optie van ouderen de voorkeur geven boven de 'no entry'-optie van bijvoorbeeld schoolverlaters (zie Willems, Borghans en De Grip, 1997). De vervangingsvraag is dan echter niet gelijk aan de uitstroom, maar alleen aan de uitstroom voor zover deze vervangen wordt. Dit impliceert dat bij een krimpende vraag de vervangingsvraag lager zal zijn dan de uitstroom van werkenden.

Overigens dient te worden beseft dat de som van de vervangingsvraag over alle beroepsgroepen niet gelijk is aan de som van de vervangingsvraag over alle opleidingstypen. Dit komt doordat de beroepsmobiliteit wel van

18. De nieuwe opleidings- en beroepenclassificatie zijn minder nauw aan elkaar verbonden als bij de oude classificatie. Door een restrictie aan te leggen door middel van de concurrentieindex (zie paragraaf 5.4) of substitutie mag plaatsvinden wordt deze oude methode alsnog benaderd. 
invloed is op de vervangingsvraag per beroepsgroep, maar geen effect heeft op de vervangingsvraag per opleidingstype. Het veranderen van beroep heeft immers geen gevolgen voor de opleidingsstructuur van de werkgelegenheid. Daarentegen kan een werkende door het afronden van een vervolgopleiding in feite 'uitstromen' naar een ander opleidingstype. In dat geval is er sprake van een vervangingsvraag bij het opleidingstype waartoe de vooropleiding van deze werkende wordt gerekend.

Voor het bepalen van de vervangingsvraag is een model ontwikkeld dat nauw aansluit bij de in demografische analyses vaker gebruikte cohort componenten methode. Deze methode baseert de berekening van de zogenaamde 'cohort change rates' op het aantal personen in hetzelfde geboortecohort die werkzaam zijn in twee verschillende tijdsperioden. Een cohort is hier een combinatie van geslacht en vijfjaars-leeftijdsklassen. Deze methode maakt gebruik van standcijfers over de geslachts- en leeftijdsopbouw van de beroepsbeoefenaren over een aantal jaren. ${ }^{19}$ Door van jaar op jaar een vergelijking te maken van de demografische opbouw in een bepaalde beroepsgroep of een bepaald opleidingstype, wordt een beeld verkregen van de netto in- of uitstroom voor de desbetreffende beroepsgroep of het desbetreffende opleidingstype. Op dit model zal hier kort worden ingegaan (zie voor een verdere toelichting Willems, 1999).

Kernpunt bij de methodiek voor de bepaling van de vervangingsvraag is de afleiding van de netto in- en uitstroomratio's, dat wil zeggen het saldo van uit- en instroom. Deze ratio's weerspiegelen de relatieve toe- of afname van het aantal werkenden in een beroepsgroep ${ }^{20}$ van een bepaald geboortecohort gedurende een bepaalde periode, waarbij de cohorten verbijzonderd worden naar geslacht. Dit kan als volgt worden weergegeven: ${ }^{21}$

$$
\dot{F}_{b x}^{t-1}=\frac{L_{b x+1}^{t}-L_{b x}^{t-1}}{L_{b x}^{t-1}}
$$

waarbij:

$\dot{F}_{b x}^{t-1}=$ netto in- of uitstroomratio van de werkenden in beroep $b$ in cohort $x$ op tijdstip $t-1$, gedurende de periode $(t-1, t)$;

$L_{b x}^{t}=$ aantal werkenden in beroep $b$ in cohort $x$ op tijdstip $t$.

Indien $\dot{F}_{b x}^{t-1}>0$ dan is er voor beroep $b$ sprake van netto instroom voor werkenden in cohort $x$. Als $\dot{F}_{b x}^{t-1}<0$ dan is er voor beroep $b$ sprake van netto uitstroom voor werkenden in cohort $x$. De vervangingsvraag die wordt opgevuld door (her-)intredende personen van hetzelfde cohort (combinatie van geslacht én leeftijdsklasse) kan niet uit de beschikbare data worden afgeleid en wordt derhalve ook niet expliciet bij de bepaling van de vervangingsvraag meegenomen. Dit houdt in dat wordt aangenomen dat een meer dan normaal (op basis van het verleden) geachte aantal herintreders in de wachtrij voor nieuwe banen achteraan moet sluiten bij de nieuw op de markt komende schoolverlaters (zie ook Borghans, De Grip en Willems, 1995).

Vervolgens wordt er gebruik gemaakt van een 'fixed-effect-model', waarbij de netto in- of uitstroomratio's worden verklaard op basis van de beroepsspecifieke afwijkingen per geslacht en leeftijdsklasse van de gemiddelde in- of uitstroompatronen uit de totale werkzame bevolking. Dit houdt in dat als een geschatte uitstroomcoëfficiënt voor een bepaalde beroepsklasse of opleidingstype sterk afwijkt, de geschatte parameter die de afwijking van het

19. Bij het opstellen van de prognoses voor de periode tot 2022 is gebruik gemaakt van naar geslacht en leeftijdsklasse verbijzonderde gegevens over het aantal werkenden per beroepsgroep en opleidingstype voor de periode van 2007 tot 2016.

20. De methodiek is hier uitgewerkt voor de vervangingsvraag per beroepsgroep. De vervangingsvraag per opleidingstype wordt op vrijwel analoge wijze bepaald.

21. Omwille van de overzichtelijkheid van de notatie is de notatie van het leeftijds-geslachtscohort met $x$ aangegeven. 
gemiddelde aangeeft waarschijnlijk significant zal zijn. Een dergelijke aanpak garandeert dat de som van de netto stromen over de beroepen overeenkomt met de totale netto in- of uitstroom.

In formulevorm:

$$
\dot{F}_{b}=F+\sum_{x} \beta_{b x} D_{x}
$$

waarbij:

$\dot{F_{b}}=$ vector van netto in- of uitstroomratio's voor beroep $b$, met waarnemingen per geslacht, leeftijdsklasse en jaar;

$\dot{F} \quad=$ idem, maar dan voor de gehele werkzame bevolking;

$D_{x}=$ matrix met dummy-variabelen; waarden zijn gelijk aan 1 voor cohort $x$ (naar leeftijd en geslacht) en 0 elders;

$\beta_{b x}=$ geschatte parameters uit het fixed-effects model.

Vergelijking (4.6) laat zien dat de stromen van de arbeidsmarkt voor een bepaalde beroepsgroep per cohort gelijk zijn aan de gemiddelde stroom op de arbeidsmarkt van dat specifieke cohort plus de beroepsspecifieke afwijking. Onder de veronderstelling dat de niet-werkzame beroepsbevolking in de prognoseperiode gelijk blijft (de zgn. conjunctuurcorrectie, zie hieronder), wordt een voorspelling gekregen van de toekomstige uitstroom uit de werkzame bevolking. De schattingsresultaten van vergelijking (4.4) dienen als basis voor een prognose van de toekomstige netto in- en uitstroomratio's.

Vanwege de trendbreuk in de $\mathrm{EBB}^{22}$ data in 2013 (zie paragraaf 4) zijn er een paar aanpassingen doorgevoerd om de invloed hiervan te minimaliseren. Zo wordt de stroming in de periode 2012-2013 niet meegenomen in het model hierboven. Ook is ervoor gekozen om een robuustere schatter te gebruiken voor de uitstroom voor opleidingen, om ervoor te zorgen dat uitschieters niet teveel invloed hebben op de berekening van de uitstroom ${ }^{23}$. Daarvoor hebben we gekozen voor het gebruik van een M-schatter (Huber 1973). Kort gezegd volgt die de volgende stappen: $\mathrm{Na}$ een initiële OLS-regressie wordt gekeken naar de residuen voor elk punt ten opzichte van de geschatte standaarddeviatie, en op basis daarvan worden gewichten toegekend aan elk datapunt. Als de afwijking erg groot is, wordt het gewicht op 0 gezet. Vervolgens wordt met weighted least squares (WLS) een nieuwe schatting gemaakt, waarbij we het proces herhalen totdat we een convergentie hebben van alle coëfficiënten in het model. Ook is er een test gedaan om alleen de uitstroom mee te nemen voor de jaren na de breuk, maar dit leidde tot te extreme voorspellingen door het tekort aan data.

Deze uitstroomcoëfficiënten worden geprojecteerd op de geconstrueerde reeks van werkenden voor ieder prognosejaar om zo een prognose te kunnen maken van de uitstroom in de komende jaren. ${ }^{24}$. Vervolgens zijn de geschatte uitstroomcoëfficiënten opgelegd aan het aantal werkenden per opleiding en beroep in 2016. Voor de uitstroom naar pensioen is voor elk geboortejaar de pensioenleeftijd gehanteerd.

Deze prognose is voor alle cohorten van de beroepsbevolking gecorrigeerd voor de verwachte verandering in de arbeidsparticipatie. De reeks van werkenden voor ieder prognosejaar wordt namelijk voorspeld aan de hand van de werkenden in het basisjaar, de door het CPB opgestelde prognoses van de (bruto) participatiegraad per cohort en opleidingsniveau van het Centraal Planbureau en de beroepsbevolkingsprognoses (CPB 2009a).

22. Bij beroepen met afwijkende aantallen voor 2016 zijn tevens correcties doorgevoerd om met een meer representatief aantal te werken voor de prognoses

23. Dit is exclusief de eerste leeftijdsgroep van 15 tot 19 jaar. Door de grote hoeveelheid bijbanen onder scholieren is het normaal een hoge piekuitstroom te hebben bij lage opleidingen.

24. Zie Cörvers, Kriechel en Montizaan (2006) voor een scenario-analyse van de vervangingsvraag. Uit deze studie blijkt tevens de beperkte gevoeligheid in de vervangingsvraag voor afwijkingen van de toekomstige ontwikkeling van de participatiegraad voor vier verschillende scenario's. 
Naast deze participatiecorrectie vindt ook een vergelijkbare correctie plaats voor de conjuncturele situatie in de analyseperiode. Figuur 4.3 bevat een samenvattend overzicht van de methodiek van het opstellen van de prognoses voor de vervangingsvraag. ${ }^{25}$

De correctie voor de conjuncturele situatie is gelijk aan het verschil tussen de verandering in het totale aantal werkende personen en de verandering in de beroepsbevolking in de historische periode. Deze correctie compenseert de uitstroom van werkenden die werkloos zijn geraakt door conjuncturele fluctuaties in het werkgelegenheidsniveau. De correctie voor de verandering in de participatiegraad is het verschil tussen de groei in de beroepsbevolking in de historische periode en de voorspelperiode.

25. Zie Shah en Burke (2001) voor een vergelijking van de methodiek van de vervangingsvraag naar beroep tussen Australië, de Verenigde Staten en Nederland. 


\section{Figuur 4.3}

Samenvattend overzicht van de methodiek van de vervangingsvraag (excl. specifieke aanpassingen en 'doorleerderscomponent')

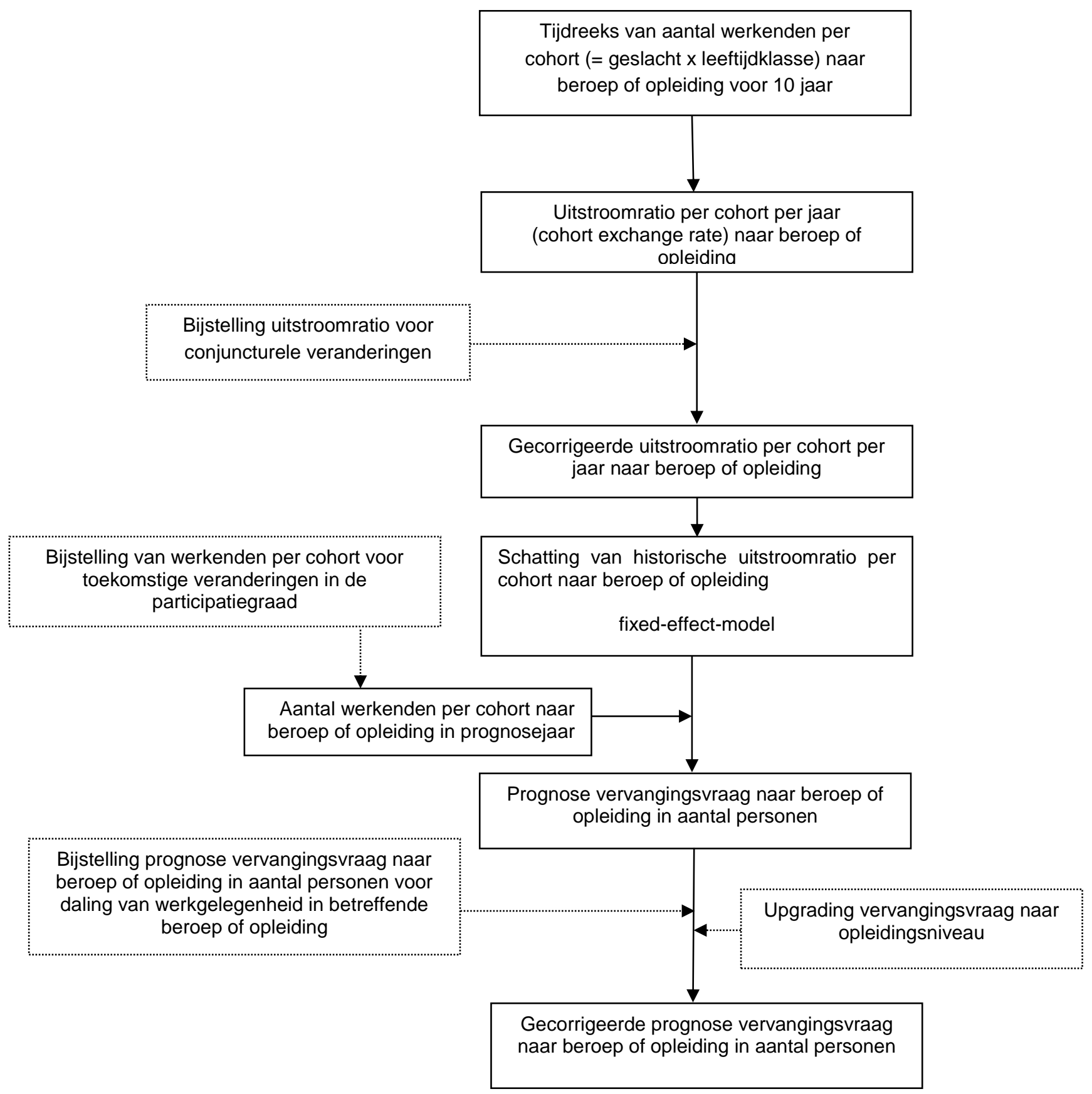


Als de correcties voor de conjunctuur en de participatiegraad gecombineerd worden dan levert dit de voorspelde toekomstige uitstroomratio per cohort op:

$$
\dot{F}_{b x}^{t, m}=\dot{F}_{b x}^{t, n}-\dot{W} P_{x}^{t, n}+\dot{L} F_{x}^{t, n}+\dot{L} F_{x}^{t, m}-\dot{L} F_{x}^{t, n}
$$

waarbij:

$\dot{F}_{b x}^{t, m}=$ de verwachte gemiddelde jaarlijkse netto in- of uitstroomratio van werkenden in beroep $b$, in cohort $x$ op tijdstip $t$ gedurende de voorspelperiode $(t+1, t+m)$;

$\dot{F}_{b x}^{t, n} \quad=$ de verwachte gemiddelde jaarlijkse netto in- of uitstroomratio van werkenden in beroep $b$, in cohort $x$ op tijdstip $t$-n gedurende de periode $(t-n, t)$;

$\dot{W} P_{x}^{t, n}=$ de gemiddelde jaarlijkse groeiratio van het totale aantal werkende personen in cohort $x$ op tijdstip $t-n$ gedurende de periode $(t-n, t)$;

$\dot{L} F_{x}^{t, n}=$ de gemiddelde jaarlijkse groeiratio van de beroepsbevolking in cohort $x$ op tijdstip $t$ - $n$ gedurende de periode $(t-n, t)$;

$\dot{L} F_{x}^{t, m}=$ de verwachte gemiddelde jaarlijkse groeiratio van de beroepsbevolking in cohort $x$ op tijdstip $t$ gedurende de voorspelperiode $(t+1, t+m)$.

De toekomstige vervangingsvraag wordt in feite op dezelfde manier bepaald als de vervangingsvraag in de historische periode. Dit houdt in dat voor beroepsgroepen met een verwachte stijging van de werkgelegenheid de vervangingsvraag gelijk is aan de netto uitstroom. De ontwikkeling van de werkgelegenheid per beroepsgroep wordt per geslacht afzonderlijk bekeken. Voor opleidingstypen en beroepsgroepen waarbij met een historische daling in de werkgelegenheid van minimaal 15\% over de komende 5 jaar, wordt de vervangingsvraag voor de prognoseperiode, relatief naar de te verwachte krimp naar beneden bijgesteld met als minimum nul. ${ }^{26}$

Voor opleidingstypen vindt daarnaast nog een upgrading van het opleidingsniveau plaats. Deze upgrading corrigeert voor de ervaring die veel arbeidsmarktverlaters hebben, maar niet in hun opleidingsniveau wordt uitgedrukt. Een mbo'er die met pensioen gaat zal vanwege zijn ervaring niet vervangen kunnen worden door een mbo'er die net zijn of haar opleiding heeft afgerond. Om hier rekening mee te houden wordt er een herverdeling van de vervangingsvraag over de opleidingsniveaus toegepast. Een gedeelte van de vervangingsvraag van iedere opleidingsniveau zal worden herverdeelt naar hogere opleidingsniveaus. Bij deze herverdeling wordt onderscheid gemaakt tussen technische en niet-technische beroepen. Van groot belang is dat het hier slechts om een herverdeling van de vervangingsvraag gaat over de opleidingsniveaus en de totale vervangingsvraag hierdoor niet verandert.

\subsection{Methodiek instroom van schoolverlaters op de arbeidsmarkt}

Voor het bepalen van de aanbodzijde van de arbeidsmarkt zijn prognoses nodig voor de instroom. De prognoses van de instroom op de arbeidsmarkt zijn gebaseerd op een verdeelmodel, dat een stapsgewijze modulaire opbouw heeft. Figuur 4.4 geeft een schematisch overzicht van deze opbouw. In het prognosemodel worden globaal gesproken twee stappen onderscheiden. In de eerste stap wordt de prognose opgesteld van de verwachte toekomstige uitstroom uit het regulier voltijdonderwijs.

26. Deze daling wordt geschat op basis van een trend over de laatste 10 jaar, met een aparte tijdsdummy voor 2013-2016. Deze methode van trendberekening is onder andere gebruikt in (Bijlsma et al., 2015a). Ook is hier een aparte schatting gemaakt voor 55+'ers en degene onder 55 geweest wanneer de trendbreuk in de twee leeftijdsgroepen tot grote verschillen leidden ( $>1 \%$ verschil in vervangingsvraag per jaar). 
Figuur 4.4

Globaal schema ter bepaling van de verwachte toekomstige instroom van schoolverlaters op de arbeidsmarkt naar ROAopleidingstype

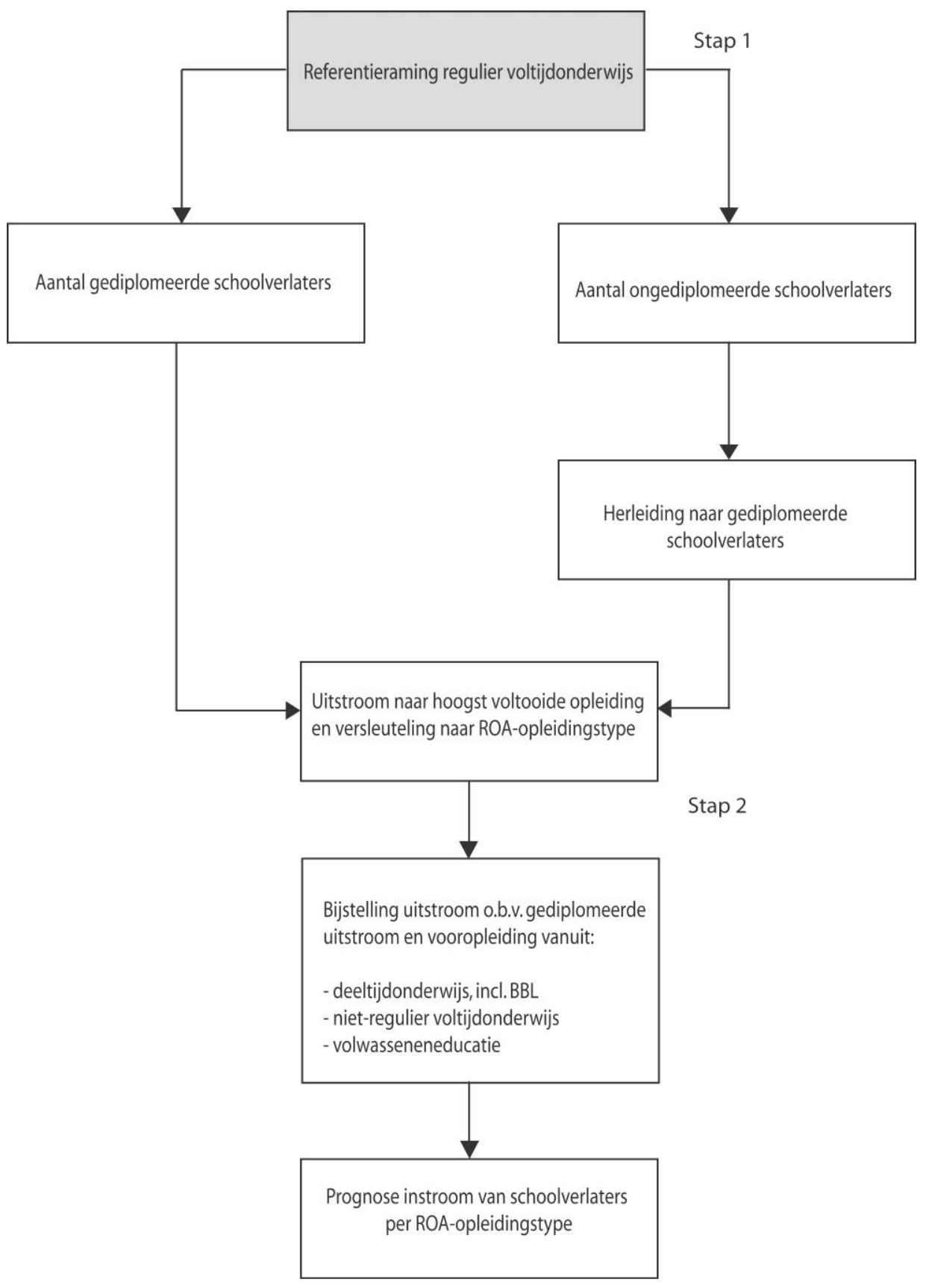


Niet voor alle schoolverlaters eindigt na het verlaten van het regulier voltijdonderwijs echter de schoolloopbaan. $\mathrm{Na}$ het verlaten van het voltijdonderwijs kan men immers nog doorstromen naar het deeltijdonderwijs, inclusief de beroepsbegeleidende leerweg (BBL, het voormalige leerlingwezen), het niet-reguliere voltijdonderwijs en de beroepsgerichte volwasseneneducatie. Als men daar een diploma behaald heeft en de gevolgde opleiding heeft een hoger niveau of een andere opleidingsrichting dan de genoten vooropleiding, dan moet de instroomprognose worden bijgesteld. Deze bijstelling vindt plaats in de tweede stap.

\section{Stap 1}

Figuur 4.5 geeft een overzicht van de opzet van stap 1 van het prognosemodel. De gebruikte databronnen zijn weergegeven in de grijsgetinte vakken. Uitgangspunt bij de bepaling van de verwachte toekomstige instroom van schoolverlaters op de arbeidsmarkt is de beleidsarme variant van de Referentieraming van het Ministerie van Onderwijs, Cultuur en Wetenschap (2017). Uit de Referentieraming worden de prognoses van het aantal schoolverlaters naar niveau en richting voor het voltijdonderwijs gebruikt. ${ }^{27}$ Hierbij is in de Referentieraming een onderscheid gemaakt tussen de schoolverlaters met diploma en de schoolverlaters zonder diploma. Degenen die het regulier voltijdonderwijs zonder diploma verlaten, kunnen eerder een opleiding met diploma hebben afgesloten. De ongediplomeerde schoolverlaters worden daarom toegewezen aan hun eerdere hoogst voltooide vooropleiding in het voltijdonderwijs. Deze hoogst voltooide voltijdopleiding wordt vastgesteld aan de hand van de Onderwijsmatrix 2016 van DUO (Dienst Uitvoering Onderwijs). Dit resulteert in het verwachte aantal schoolverlaters met diploma per opleidingsniveau en -richting.

De indeling van opleidingen op basis van de Onderwijsmatrix heeft een hoger aggregatieniveau dan de indeling die het ROA hanteert. Daarom vindt er een uitsplitsing plaats om de toekomstige uitstroom uit het regulier voltijdonderwijs naar de arbeidsmarkt per ROA-opleidingstype te bepalen. Deze verdeling wordt gemaakt met behulp van gegevens over het aantal gediplomeerden van elk opleidingstype binnen een schoolsoort, de DUO onderwijsmatrix tellingen. ${ }^{28}$ De gebruikte gegevens hebben betrekking op de periode van gediplomeerden van schooljaar 2006-2007 tot en met schooljaar 2015-2016. Op basis van deze gegevens wordt door middel van 'exponential smoothing' de verwachte trend in het aantal gediplomeerden per opleiding voor de periode tot 2022 berekend, daarbij rekening houdend met de randtotalen uit de Referentieraming.

In de DUO onderwijsmatrix tellingen wordt van de gediplomeerden zowel de referentieraming codering als de opleidingscodering (crebo of croho) weergegeven. Daarmee wordt de verdeling van de referentieraming aantallen naar de ROA-opleidingstype indeling bekend verondersteld. Omdat niet alle gediplomeerden uit de DUO tellingen ook het onderwijs verlaten kan de verdeling van gediplomeerden afwijken van de gediplomeerde schoolverlaters uit de referentieraming. Op basis van informatie over de vervolgopleiding van schoolverlaters anderhalf jaar na afstuderen uit de vo, bve, hbo en wo monitor wordt het aandeel schoolverlaters van de gediplomeerden uit de DUO onderwijsmatrixtellingen bepaald.

Op de resulterende prognoses wordt nog een laatste correctie uitgevoerd. ${ }^{29}$ Personen die na een bepaalde periode van afwezigheid terugkeren in het onderwijs worden in de Referentieraming als schoolverlaters beschouwd terwijl zij in feite doorstuderen. Aan de hand van gegevens van het CBS over de opleidingsachtergrond van deze groep, wordt er gecorrigeerd voor de zogenaamde indirecte instroom in een opleiding (zie Cörvers en Golsteyn, 2003). Na stap 1 zijn de instroomprognoses voor schoolverlaters en afgestudeerden van het voltijdonderwijs gereed.

27. Het betreft hier degene die het onderwijs verlaten en naar buiten bekostigd onderwijs gaan.

28. De cijfers voor het vo, mbo en ho kunnen aan de hand van crebo- ofwel croho-codes gekoppeld worden met een conversieschema van het CBS aan de cto indeling en isced97 field bepaling van het CBS. Die conversie is nodig om de ROA opleidingstype indeling te kunnen bepalen (zie ROA 2016).

29. Voor een uitvoerigere beschrijving van de methodiek, zie Cörvers en Golsteyn (2003). 
In stap 2 wordt, zoals reeds is aangegeven, de instroomprognose aangepast door rekening te houden met de doorstroom naar de beroepsbegeleidende leerweg (BBL, het voormalige leerlingwezen), het overige deeltijdonderwijs, het niet-reguliere voltijdonderwijs of de beroepsgerichte volwasseneneducatie. Om een prognose te maken van het aantal schoolverlaters van de beroepsbegeleidende leerweg, wordt als randtotaal de prognose uit de Referentieraming van de beroepsbegeleidende leerweg genomen. Dit randtotaal wordt opgesplitst door de aantallen schoolverlaters die aan de hand van de DUO onderwijsmatrixtellingen naar opleidingsrichting met 'exponential smoothing' zijn voorspeld, als verdeelsleutel te gebruiken. Hierin verschilt de methodiek niet van de voltijdschoolverlaters van de beroepsopleidende leerweg $(\mathrm{BOL}) .^{30}$

\section{Figuur 4.5}

Globaal overzicht van de eerste stap van de instroomprognoses van schoolverlaters op arbeidsmarkt

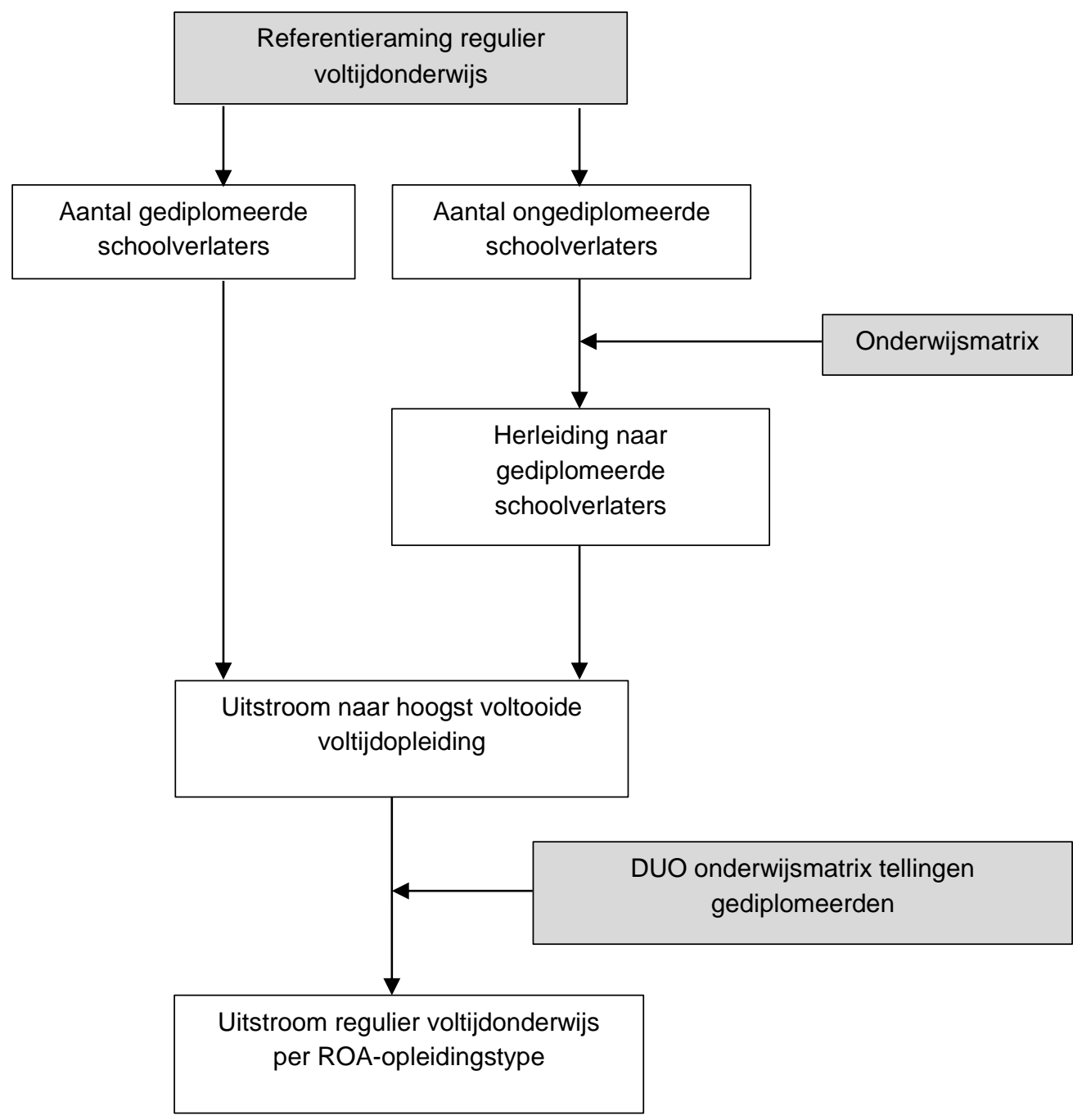

30. De voorspelde aantallen per vooropleiding van de BBL-schoolverlaters worden echter vervolgens tot vervangingsvraag naar deze opleidingen gerekend (zie paragraaf 4.3). Dit komt doordat de BBL'ers als werkenden beschouwd worden. Indien zij hun opleidingsplaats verlaten, komt hun baan voor nieuwe werkende BBL-leerlingen. 
Voor het samenstellen van de prognoses van het aantal schoolverlaters dat uit het niet-reguliere onderwijs op de arbeidsmarkt instroomt, zijn er ten opzichte van de prognoses voor de beroepsbegeleidende leerweg een aantal verschillen. In de eerste plaats zijn er geen randtotalen uit de Referentieraming beschikbaar voor deze schoolverlaters. Dit betekent dat de prognoses van het aantal schoolverlaters per opleidingstype die op grond van de gegevens uit de EBB zijn samengesteld, als absolute aantallen worden meegenomen in de instroomprognose.

Ten tweede zijn er in het niet-reguliere onderwijs, voltijd- en deeltijdschoolverlaters. Alle deeltijdschoolverlaters (die niet BBL volgden) worden tot het niet-reguliere onderwijs gerekend, en worden meegenomen in de instroomprognose volgens de hierboven vermelde methodiek. In de EBB zijn de schoolverlaters met niet-regulier onderwijs echter niet te onderscheiden van degenen met regulier onderwijs. Dit onderscheid is van belang omdat de schoolverlaters van het reguliere onderwijs al in stap 1 zijn meegenomen. Op grond van De Grip en Jacobs (1999) behoren schoolverlaters tot het reguliere onderwijs als de gevolgde opleiding aan de criteria in Tabel 4.1 voldoen. Ten opzichte van De Grip en Jacobs (1999) is afgeweken van het criterium van 4 jaar of langer voor de opleidingsduur van reguliere mbo-opleidingen. Ook mbo-opleidingen die 2 of 3 jaar duren kunnen worden beschouwd als regulier onderwijs (zie bijv. de Wet Educatie en Beroepsonderwijs).

Tabel 4.1

Criteria waaraan moet worden voldaan om een opleiding als regulier te definiëren

\begin{tabular}{lll} 
Opleidingsniveau & Leeftijd bij diplomering & Opleidingsduur \\
& & \\
\hline vmbo theorie & $\leq 19$ jaar & \\
vmbo & $\leq 20$ jaar & \\
havo & $\leq 19$ jaar & $\geq 2$ jaar \\
vwo & $\leq 20$ jaar & $\geq 3$ jaar \\
mbo & $<24$ jaar & $\geq 4$ jaar \\
hbo & $\geq 21$ jaar en $<30$ jaar & \\
wo & $\geq 22$ en $\leq 30$ jaar
\end{tabular}

Bron: bewerking van De Grip en Jacobs (1999)

Alleen schoolverlaters die buiten de criteria van Tabel 4.1 vallen worden beschouwd als uitstroom uit het nietreguliere onderwijs, en worden derhalve in stap 2 meegenomen als instroom op de arbeidsmarkt. Om een prognose te maken van het aantal schoolverlaters van het niet-reguliere onderwijs wordt gebruik gemaakt van de Enquête Beroepsbevolking van het CBS (EBB $2001 \mathrm{t} / \mathrm{m}$ 2012). Daartoe worden op basis van de ROAopleidingsclassificatie (combinatie van cto codering van niveau en isced1997 field bepaling van richting) de personen geselecteerd voor wie geldt dat het actuele onderwijs ten opzichte van het hoogst behaalde onderwijs niveau verhogend en/of richting veranderend is. Vervolgens wordt er op basis van de gegevens over de begindatum van de studie en de verwachte studieduur een schatting gemaakt van wanneer de studenten op de arbeidsmarkt instromen. Op dat moment wordt de hoogst behaalde opleiding op het moment van de enquête beschouwd als vooropleiding en de actuele opleiding als de hoogst behaalde opleiding.

$\mathrm{Na}$ de bijstelling van de arbeidsmarktinstroom van het reguliere voltijdonderwijs met de arbeidsmarktinstroom van het BBL en het niet-reguliere onderwijs in stap 2 resulteert de toekomstige instroom van schoolverlaters op de arbeidsmarkt per ROA-opleidingstype voor de prognoseperiode 2017-2022.

\subsection{Baanopeningen en typering arbeidsmarktperspectieven}

Voor de opleidingen kunnen de verwachte vraag naar nieuwkomers en het verwachte aanbod aan elkaar worden gerelateerd. De verwachte vraag is gelijk aan het aantal baanopeningen dat in de prognoseperiode ontstaat als gevolg van de uitbreidings- en vervangingsvraag. Voor zover nieuwkomers op de arbeidsmarkt hinder ondervinden van een krimpende werkgelegenheid, wordt dit met de vervangingsvraag verrekend (zie paragraaf 
4.3). De vervangingsvraag wordt immers alleen beïnvloed door de uitstroom van werkenden voor zover dit tot nieuwe vraag leidt.

Voor nieuwkomers op de arbeidsmarkt is de uitstroom van werkenden van de arbeidsmarkt alleen relevant indien door het verloop nieuwe vacatures ontstaan. ${ }^{31}$ Omdat ook de uitbreidingsvraag een netto-grootheid is geldt per definitie dat in geval van een groeiende werkgelegenheid de vervangingsvraag gelijk is aan het verloop. Als de werkgelegenheid krimpt, zijn er meer uitstromers dan instromers. Dit verschil is ook per definitie gelijk aan de (negatieve) uitbreidingsvraag. Het verband tussen vervangingsvraag en uitstroom ligt dus, bij een gegeven uitbreidingsvraag, vast. Er geldt:

vervangingsvraag $=$ uitstroom $+\mathrm{MIN}\{$ uitbreidingsvraag, 0$\}$

Op basis van deze identiteit kan het aantal baanopeningen op twee manieren worden vastgesteld. Ten eerste kan men uitgaan van de uitstroom en deze salderen met de uitbreidingsvraag:

baanopeningen $=$ uitstroom + uitbreidingsvraag

De tweede mogelijkheid is uit te gaan van de vervangingsvraag en hierbij, indien er sprake is van een groeiende werkgelegenheid, de uitbreidingsvraag op te tellen:

baanopeningen $=$ vervangingsvraag $+\operatorname{MAX}\{0$, uitbreidingsvraag $\}$

Substitutie van de definitie van vervangingsvraag (4.8) in de laatste vergelijking laat zien dat beide methodes gelijkwaardig zijn. De definitie op basis van de vervangingsvraag laat bovendien zien dat het aantal baanopeningen nooit negatief kan zijn. Naast het totaal aantal baanopeningen uit hoofde van uitbreidings- en vervangingsvraag wordt aan de vraagkant rekening gehouden met de substitutievraag (zie paragraaf 4.2).

Als aanbod op de arbeidsmarkt is de som genomen van de verwachte instroom in de periode 2011-2016 en het aantal kortdurig werklozen aan het begin van de prognoseperiode (personen die korter dan één jaar werkloos zijn). Dit laatste is op te vatten als het boven de markt zwevende aanbod van werklozen aan het begin van de prognoseperiode. De bepaling van het aantal kortdurig werklozen is gebaseerd op het totaal aantal werklozen per opleidingstype volgens de EBB, vermenigvuldigd met het aandeel werklozen dat hooguit een jaar werkloos is. Dit aandeel is bepaald met behulp van gegevens van het CBS. Vervolgens wordt de Indicator Toekomstige Arbeidsmarktperspectieven (ITA) bepaald volgens de formule:

$$
I T A=\frac{(100+\text { instroom } \%+\text { kortdurig werklozen } \%)}{(100+\max \{0, \text { uitbreidin gsvraag } \%\}+\text { vervangingsvraag } \%+\text { substitutievraag } \%)}
$$

Naarmate de waarde van de ITA hoger ligt, is er sprake van een slechter arbeidsmarktperspectief. Anders gezegd, de inspanning die men moet leveren om een baan te kunnen bemachtigen is groter naarmate de ITA hoger is. Een waarde rond de 1 duidt op een evenwichtssituatie. Om te bewerkstelligen dat de grens tussen een goed en een redelijk perspectief precies bij 1 ligt en om discrepanties tussen de ITA en de typering te voorkomen, wordt de ITA naar boven afgerond (zie Wieling, De Grip en Willems, 1990).

31. Op de relatie tussen vacatures enerzijds en baanopeningen anderzijds wordt nader ingegaan in De Grip, Meijboom en Willems (1995). 


\subsection{Typering knelpunten in de personeelsvoorziening}

\section{Knelpunten naar opleidingstype}

Naast de verwachte arbeidsmarktsituatie voor nieuwkomers is ook ingegaan op de verwachte knelpunten in de personeelsvoorziening. De indicator hiervoor is in principe het spiegelbeeld van de ITA. Als de vraag naar werkenden met een bepaalde opleidingsachtergrond groter is dan het aanbod kunnen knelpunten in de personeelsvoorziening verwacht worden. Vergelijkbaar met de Indicator Toekomstige Arbeidsmarktperspectieven (ITA) geeft de Indicator van de Toekomstige Knelpunten in de Personeelsvoorziening (ITKP) deze vraagaanbodspanning aan. Bij een krimpende werkgelegenheid voor een bepaald opleidingstype wordt de totale vraag ('recruteringsbehoefte') echter op een enigszins andere wijze berekend dan het aantal baanopeningen voor nieuwkomers op de arbeidsmarkt. Verschil met de ITA is dat bij de ITKP de uitstroom van werkenden als gevolg van een krimpende werkgelegenheid is meegerekend in de vraag, omdat verwacht mag worden dat bij knelpunten in de personeelsvoorziening deze (gedwongen) uitstroom kan worden afgeremd of elders werk zou kunnen vinden. Zeker wanneer bedrijven geconfronteerd worden met een krappe arbeidsmarkt voor een bepaald opleidingstype, zullen zij van deze mogelijkheid gebruik maken. Voor het overige is de Indicator Toekomstige Knelpunten in de Personeelsvoorziening (ITKP) gelijk aan de ITA. Naarmate de waarde van de indicator lager wordt, zijn de verwachte knelpunten in de personeelsvoorziening groter.

$$
I T K P=\frac{(100+\text { instroom } \%+\text { kortdurig werklozen } \%)}{(100+\text { uitbreidin gsvraag } \%+\text { vervangingsvraag } \%+\text { substitutievraag } \%)}
$$

\section{Knelpunten naar beroepsgroep}

Voor het indiceren van de knelpunten in de personeelsvoorziening naar beroepsgroep kan niet een soortgelijke aanpak worden gevolgd, omdat het aanbod per beroepsgroep niet goed is vast te stellen. Daarom is een indicator ontwikkeld waarvoor geen voorspellingen van het arbeidsaanbod naar beroep nodig zijn.

De knelpunten in de personeelsvoorziening naar beroepsgroep nemen de prognoses van vraag en aanbod naar opleidingstype als uitgangspunt. Daarbij is als volgt te werk gegaan.

Het aanbod van een opleidingstype $i$ op tijdstip $t$ is gelijk aan het aanbod op tijdstip $t$-1 (het 'basisjaar' van de prognoseperiode) plus de arbeidsmarktinstroom van schoolverlaters in de periode tussen $t-1$ en $t$ minus de vervangingsvraag over dezelfde periode. Bij het aanbod is dit jaar niet alleen rekening gehouden met het aanbod van kortdurig werklozen en de instroom naar opleiding, maar ook met het verwachte aanbod van scholieren met bijbanen. Dit bleek noodzakelijk in verband met de overgang naar de internationale definitie van arbeid. Door deze definitie telt de beroepsbevolking veel kleine banen van jongeren die nog niet in de instroom zijn verdisconteerd, maar wel een bijbaan als scholier hebben (Bijlsma et al., 2015b). Wanneer hier geen rekening mee wordt gehouden, wordt het toekomstig aanbod in beroepen waar veel gebruik wordt gemakt van werkende scholieren (bijvoorbeeld vakkenvullers) onderschat.

De vraag naar een opleidingstype $i$ op tijdstip $t\left(\right.$ vraag $\left._{i, t}\right)$ is gelijk aan de vraag op tijdstip $t-1$ plus de som van uitbreidings-, substitutie- en vervangingsvraag in de periode tussen $t-1$ en $t$. Dit resulteert in de volgende twee vergelijkingen:

$$
\begin{aligned}
& \operatorname{aanbod}_{i, t}=L_{i, t-1}+w l h_{i, t-1}+i n_{i}+s_{i}-v v_{i} \\
& \operatorname{vraag}_{i, t}=L_{i, t-1}+u v_{i}+s v_{i}+v v_{i}
\end{aligned}
$$

waarbij

$L_{i, t-1} \quad$ het totaal aantal werkenden met opleiding $i$ in $t-1$; 


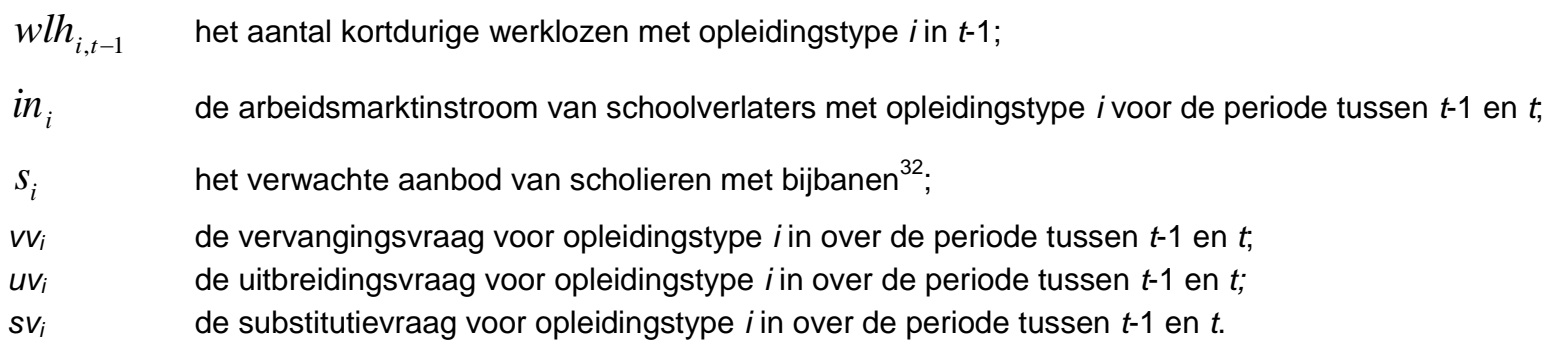

De kans om een werknemer aan te trekken met opleidingstype $i$ wordt gegeven door:

$$
\begin{array}{ll}
p_{i}=\frac{\operatorname{aanbod}_{i, t}}{\operatorname{vraag}_{i, t}} & \text { als aanbod } \\
p_{i}=1 & \leq \operatorname{vraag}_{i, t} \\
& \text { als aanbod } \\
i, t & >\operatorname{vraag}_{i, t}
\end{array}
$$

We veronderstellen dus dat de kans om iemand met opleidingstype $i$ aan te trekken gelijk is voor alle beroepsgroepen. Dat betekent dat tekorten proportioneel over beroepen verdeeld zullen zijn.

De alternatieve indicator voor de toekomstige knelpunten in de personeelsvoorziening naar beroepsgroep $\left(I T K B_{j}\right)$, als gevolg van aanbodtekorten bij opleidingen waaruit de werkenden in beroep $j$ worden gerekruteerd, wordt dan gegeven door:

$$
I T K B_{j}^{*}=\frac{\sum_{i} p_{i} x_{i j, t-1}}{\sum_{i} x_{i j, t-1}} ; \quad 0 \leq I T K B_{j}^{*} \leq 1
$$

De $I T K B_{j}^{*}$ is een relatieve maatstaf voor knelpunten. De noemer geeft de totale vraag vanuit beroepsgroep $j$ en de teller de verwachte vervulling van deze vraag. De $I T K B_{j}^{*}$ geeft dus de mate waarin de vraag vanuit beroepsgroep $j$ in de gewenste samenstelling vervuld zal kunnen worden. Naarmate de waarde van $I T K B_{j}^{*}$ lager is, zijn er meer knelpunten te verwachten. Als $I T K B_{j}^{*}=1$ dan worden er geen knelpunten verwacht bij het vervullen van de vraag vanuit beroepsgroep $j$. Een $I T K B_{j}^{*}$ van 0 betekent dat de vraag vanuit beroep $j$ in het geheel niet vervuld kan worden.

De indicator wordt gecorrigeerd voor twee factoren. Ten eerste, het aanbod per beroepsgroep dat beschikbaar is voor werkgevers indien er sprake is van een krimpende beroepsgroep ( $\mathrm{vgl}$. ITKP $\mathrm{P}_{\mathrm{i}}$. Dit aanbod kan worden verrekend in de teller van vergelijking (4.15). Het aantal personen dat moet afvloeien ten gevolge van krimp tussen $t-1$ en $t$ is bekend op basis van de uitbreidingsvraag naar beroepsgroep $\left(u v_{j}\right)$. Het gaat bij deze krimp $(\operatorname{MIN}(u v j ; 0))$ alleen om het deel waarvoor de verschillende opleidingstypen $i$ niet in het aanbod van de betreffende beroepsgroep $j$ voorzien, dat wil zeggen $\left(1-I T K B_{j}^{*}\right)^{*} \operatorname{MIN}\left(u v_{j} ; 0\right)$. Dit is de factor waarmee de oorspronkelijke $I T K B_{j}^{*}$ wordt vermenigvuldigd. Ten tweede, de groei van beroepsgroep $j$ verergert eventueel knelpunten in de personeelsvoorziening. Het is dan moeilijker om de bestaande personele samenstelling met betrekking tot de opleidingstypen te continueren. Derhalve moet in vergelijking (4.15) de verwachte toekomstige werkgelegenheid 
de noemer $\sum_{i} x_{i j, t-1}=x_{j, t-1}$ gecorrigeerd worden voor de stijging in de werkgelegenheid. Hier gaat het om de verwachte toename van de werkgelegenheid per beroepsgroep, i.e. de uitbreidingsvraag $u v_{j}$, maar alleen het deel dat uit het aanbod van de verschillende opleidingstypen kan worden voldaan. Dit deel bestaat derhalve uit ( $\left.I T K B_{j}^{*}\right)^{\star} \operatorname{MAX}\left(u v_{j} ; 0\right)$. De aangepaste $I T K B_{j}$ is dan gedefinieerd volgens vergelijking (4.16).

$$
I T K B_{j}=I T K B_{j}^{*} \frac{x_{j, t-1}-\left(1-I T K B_{j}^{*}\right)\left(\operatorname{MIN}\left(u v_{j} ; 0\right)\right.}{x_{j, t-1}+\left(I T K B_{j}^{*}\right) M A X\left(u v_{j} ; 0\right)}
$$

Deze indicator heeft echter een nadeel. De indicator geeft aan in welke mate het mogelijk is om de gewenste personeelssamenstelling te bereiken maar houdt geen rekening met de mogelijkheid om tekorten bij een opleiding aan te vullen door mensen met een andere (aanverwante) opleiding te rekruteren. Met eventuele substitutieprocessen wordt dus geen rekening gehouden. Dit impliceert dat een eventuele vermindering van de knelpunten als gevolg van passief substitutie-aanbod vanuit andere opleidingen in deze alternatieve indicator niet tot uiting komen. 


\section{De structurele arbeidsmarktsituatie}

\section{$5.1 \quad$ Inleiding}

Naast de informatie over de actuele arbeidsmarktsituatie en de prognoses voor de ontwikkelingen op de arbeidsmarkt voor de middellange termijn, verschaft het informatiesysteem onderwijs-arbeidsmarkt ook inzicht in de structurele arbeidsmarktpositie van beroepsgroepen en opleidingstypen. Deze indicatoren beogen de kracht of kwetsbaarheid van een bepaalde beroepsgroep of opleidingsachtergrond op de arbeidsmarkt aan te duiden, ongeacht de specifieke actuele situatie of de voorspelde ontwikkelingen in de vraag-aanbodverhoudingen.

Het gaat hierbij om de indicator voor de conjunctuurgevoeligheid van de werkgelegenheid en de indicatoren voor de uitwijkmogelijkheden op de arbeidsmarkt. Daarnaast is ook gebruik gemaakt van een indicator voor de substitutiemogelijkheden die werkgevers hebben tussen arbeidskrachten met uiteenlopende opleidingsachtergronden en de concurrentie-index die aangeeft welke opleidingen een sterke verwantschap vertonen in hun beroependomein. Er is bovendien een nieuwe indicator opgenomen die inzicht geeft in de loopbaanperspectieven naar opleiding en beroep. Deze is berekend (per opleiding en beroep) aan de hand van het verschil in bruto uurloon van werkenden in de leeftijdsgroep 20-29 jaar en 40-49 jaar (zie voor een verantwoording Fouarge et al., 2014). Deze gegevens zijn verkregen door koppeling van informatie over lonen en gewerkte uren uit het Sociaal Statistisch Bestand (SSB) van CBS (SSB-Banen en de Polis-Bestanden) met informatie over het opleidingstype van EBB-respondenten. Deze loongroei is vervolgens ingedeeld in kwintielen. De indicator voor loopbaanperspectief neemt de volgende waarde voor de 5 oplopende kwintielen: slecht, matig, redelijk, goed, zeer goed. Beroepsgroepen en opleidingstypen waarbij het loon op middelbare leeftijd een stuk hoger ligt dan bij de eerste jaren op de arbeidsmarkt worden gezien als beroepen en opleidingstypen met goede loopbaanperspectieven.

In dit hoofdstuk wordt een aantal van deze indicatoren besproken. Eerst wordt de indicator voor de conjunctuurgevoeligheid gesproken. In de daarop volgende paragraaf wordt ingegaan op de indicatoren van en de substitutiemogelijkheden op de arbeidsmarkt en de uitwijkmogelijkheden. In de laatste paragraaf wordt ingegaan op de concurrentie-index. In Tabel B3 van Appendix B wordt een beknopte technische toelichting gegeven op deze variabelen.

\subsection{Conjunctuurgevoeligheid}

De indicator voor de conjunctuurgevoeligheid geeft aan in welke mate de werkgelegenheid voor een bepaalde beroepsgroep of opleidingstype fluctueert als gevolg van schommelingen in de werkgelegenheid van bedrijfssectoren. De conjunctuurgevoeligheid van bedrijfssectoren wordt vastgesteld op grond van: ${ }^{33}$

$$
C I_{s}=100 \sum_{t} \frac{\left|W_{s}^{t}-\bar{W}_{s}^{t}\right|}{W_{s}^{t}}
$$

waarbij:

$\mathrm{Cl}_{s} \quad$ conjunctuurgevoeligheid van bedrijfssector $s$;

$W_{s}^{t} \quad$ de werkgelegenheid in bedrijfssector $s$ in jaar $t$;

$\bar{W}_{s}^{t} \quad$ de trend van de werkgelegenheid in bedrijfssector $s$ in jaar $t$.

De trend wordt berekend als:

33. De conjunctuurindicator wordt hierbij genormeerd naar de waarde 1. 


$$
\bar{W}_{s}^{t}=\frac{W_{s}^{t-1}+W_{s}^{t+1}}{2}
$$

De indicator wordt vastgesteld op basis van gegevens van het totale arbeidsvolume uit de Nationale Rekeningen voor de periode 1969 tot 2012 (zie statline.cbs.nl). In de praktijk blijken echter de productieberoepen sterker beïnvloed te worden door deze schommelingen dan andere functies. Om hiervoor te corrigeren wordt het verband vastgesteld tussen de werkgelegenheidsfluctuaties in een beroepssegment $\Delta W_{p s}^{t}$ en de schommelingen in een bedrijfssector:

$$
\Delta W_{p s}^{t}=C_{p s}+\alpha_{p s} \Delta W_{s}^{t}
$$

Dit verband is geschat op basis van de EBB van 1996 tot 2012. $\alpha_{p s}$ geeft aan in welke mate de werkgelegenheid in een bepaald beroepssegment mee fluctueert met de werkgelegenheid van de bedrijfssector. De conjunctuurgevoeligheid van een beroepsgroep $b$ is vastgesteld als: ${ }^{34}$

$$
C I_{b}=\sum_{s} \frac{W_{b s}^{t}}{W_{s}^{t}} \alpha_{p s} C I_{s}
$$

Hierbij is $p$ het beroepssegment dat beroepsgroep $b$ omvat. Omdat bij een aantal beroepen waarbij het aandeel in de werkgelegenheid in een bedrijfssector vrij klein is, de schattingen van $\alpha_{p s}$ vrij extreme waarden aannamen, is de randvoorwaarde gesteld dat $\alpha_{p s}$ tussen 0,3 en 3,0 moet liggen.

Omdat de werkgelegenheid van mensen met een bepaalde opleidingsachtergrond deels ook aanbodbepaald is, is een soortgelijke aanpak voor de berekening van de conjunctuurgevoeligheid van opleidingstypen niet zinvol. Om die reden is bij het bepalen van de conjunctuurgevoeligheid van een bepaald opleidingstype het gewogen gemiddelde genomen van de beroepsgroepen waarin degenen uit deze opleidingsachtergrond werkzaam zijn.

$$
C I_{o}=\sum_{b} \frac{W_{b o}^{t}}{W_{o}^{t}} C I_{b}
$$

\subsection{Uitwijk- en substitutiemogelijkheden}

Omdat er geen één-op-één-relatie bestaat tussen opleiding en beroep of tussen opleiding en bedrijfssector is het zinvol om aan te geven hoe breed het domein is waarin mensen met een bepaalde opleidingsachtergrond werk vinden. De maatstaf die hiervoor wordt gebruikt is de Gini-Hirschman-index. De spreiding van een opleidingstype

(o) over beroepsgroepen wordt aangegeven door:

$$
G H_{o}^{b e r}=\frac{1}{\sum_{b}\left(\frac{W_{o, b}}{W_{o}}\right)^{2}}
$$

34. Ook bij de beroepen en opleidingen wordt de conjunctuurindicator genormeerd naar de waarde 1 . 
Deze maatstaf kan geïnterpreteerd worden als het gestandaardiseerde aantal beroepen waarin men terecht komt. Bij een volledige concentratie van de werkgelegenheid in één beroepsgroep is de indicator gelijk aan 1 . Bij een gelijke spreiding over $b$ beroepsgroepen is de indicator gelijk aan $b$. Bij een ongelijke spreiding tellen beroepsgroepen met een relatief laag werkgelegenheidsaandeel minder zwaar mee dan beroepsgroepen met een groot werkgelegenheidsaandeel. Op vergelijkbare wijze kunnen de uitwijkmogelijkheden van een opleidingstype of een beroepsgroep naar bedrijfssectoren worden vastgesteld.

Daarnaast wordt een indicatie gegeven van de substitutiemogelijkheden die een werkgever heeft in de selectie van mensen met een uiteenlopende opleidingsachtergrond. Daarbij is de spreiding van de werkgelegenheid in een beroepsgroep over de opleidingstypen als volgt vastgesteld:

$$
G H_{b}^{\text {subs }}=\frac{1}{\sum_{o}\left(\frac{W_{o, b}}{W_{b}}\right)^{2}}
$$

\subsection{Concurrentie-index}

Naast het feit dat een opleidingstype tot werk in meerdere beroepen kan leiden, kan er tussen de werkgelegenheid van opleidingstypen ook een overlap bestaan. De concurrentie-index die hiervoor wordt gebruikt (zie Borghans, 1992) is afgeleid van de Gini-Hirschman-index en luidt als volgt:

$$
S_{o, o o}=\frac{\sum_{b}\left(\frac{W_{o, b}}{W_{o}}\right)\left(\frac{W_{o o, b}}{W_{o o}}\right)}{\sqrt{\sum_{b}\left(\frac{W_{o, b}}{W_{o}}\right)^{2} \sum_{b}\left(\frac{w_{o o, b}}{W_{o o}}\right)^{2}}}
$$

Deze index geeft aan hoe groot de kans is dat personen met verschillende opleidingsachtergrond (respectievelijk $o$ en oo ) in dezelfde beroepsgroep werkzaam zijn. Omdat bij opleidingstypen met een grote beroepenspreiding deze kans a priori reeds klein is, is deze voor beroepenspreiding gecorrigeerd. 


\section{Literatuur}

Bakens, J., Cörvers, F., Dijksman, S., Fouarge, D., Poulissen, D. (2018). Methodiek regionale arbeidsmarktprognoses 2017-2022. Maastricht: ROA-TR-2018/5.

Bijlsma, I., Dijksman, S., Fouarge, D., Künn-Nelen, A. (2015a). Winnaars en verliezers op de arbeidsmarkt 19962012. Tijdschrift voor Arbeidsvraagstukken, 31 (2), 106-123.

Bijlsma, I., Dijksman, S., Fouarge,D., Künn-Nelen, A., Poulissen, D. (2015b). Veranderingen in de omvang en samenstelling van de beroepsbevolking als gevolg van de overstap op de ILO-definitie van de beroepsbevolking. ROA-TR-2015/6, Maastricht University.

Borghans, L. (1992), A Histo-Topographic Map of the Dutch University Studies. ROA-W-1992/5E, Maastricht University.

Borghans, L. (1996). Effects of supply and demand on the employment structure. Mimeo, Maastricht University.

Borghans, L., Grip, A. de., Heijke, H. (2000). Alice in prognoseland. Over de zin van arbeidsmarktprognoses. ROA-W-2000/6, Maastricht University.

Borghans, L., Grip, A. de, Willems, E. (1995). Herijking ROA-Informatiesysteem Onderwijs-Arbeidsmarkt. ROAR-1995/1, Maastricht University.

Borghans, L., Heijke, H. (1994). Een random-coëfficiënten-model voor het voorspellen van de beroepenstructuur van bedrijfstakken. ROA-W-1994/1, Maastricht University.

Borghans, L., Heijke, H. (1996). Forecasting the educational structure of occupations: a manpower requirement approach with substitution. Labour, 10, 151-192.

Borghans, L., Willems, E. (1998). Interpreting gaps in manpower forecasting models. Labour, 12, 633-641.

Clerx, R., Cörvers, F., Dijksman, S., Fouarge, D., Künn-Nelen, A. (2014). Methodiek arbeidsmarktprognoses en indicatoren 2013-2018. ROA-TR-2014/3, Maastricht University.

Cörvers, F. (2003). Labour market forecasting in the Netherlands: a top-down approach. In: S.L. Schmidt, K. Schömann, M. Tessaring (eds.), Early identification of skill needs in Europe, Cedefop Reference Series, Vol. 40, Thessaloniki, pp. 72-83.

Cörvers, F., Golsteyn, B. (2003). De invloed van voortijdige schooluitval op de instroomprognoses van schoolverlaters op de arbeidsmarkt. ROA-W-2003/1, Maastricht University.

Cörvers, F., Grip, A. de, Heijke, H. (2002). Beyond manpower planning: a labour market model for the Netherlands and its forecasts to 2006. In: M. Neugart and K. Schömann (eds), Forecasting Labour Markets in OECD countries, Edward Elgar, pp. 185-223.

Cörvers, F., Dupuy, A. (2006). Explaining the occupational structure of Dutch sectors of industry, 1988-2003. ROA-W-2006/7E, Maastricht University.

Cörvers, F., Dupuy, A. (2007). Beroepenmodel voor het onderwijs en de zorg: werkgelegenheid en prognoses. ROA-W-2007/3, Maastricht University.

Cörvers, F., Dupuy, A. (2010). Estimating employment dynamics across occupations and sectors of industry. Journal of Macroeconomics, 32, 17-27.

Cörvers, F., Heijke, H. (2004), Forecasting the labour market by occupation and education: Some key issues, ROA-W-2004/4, Maastricht University.

Cörvers, F., Kriechel, B., Montizaan, R. (2006). Scenario-analyse van de vervangingsvraag. ROA-W-2006/1, Maastricht University.

CPB (1990). ATHENA Een bedrijfstakkenmodel voor de Nederlandse economie. Werkdocument No. 30, Den Haag.

CPB (2005). Werkgelegenheid en toegevoegde waarde per bedrijfstak, 2001-2020 en 2021-2040. Den Haag.

CPB (2006). Athena: A multi-sector model of the Dutch economy. CPB Document No. 105, Den Haag.

CPB (2017a). Centraal Economisch Plan 2017. Den Haag.

CPB (2017b). Actualisatie middellangetermijnverkenning 2018-2021 (verwerking regeerakkoord), Den Haag.

Dupuy, A. (2006). Measuring skill-upgrading in the Dutch labor market. ROA-W-2006/3E, Maastricht University. 
Eijs, P. van, Grip, A. de (1998). De ontwikkeling van het project onderwijs-arbeidsmarkt 1986-1998. ROA-W1998/7, Maastricht University.

Fouarge, D. (2015). Project Onderwijs-Arbeidsmarkt: Gebruik van arbeidsmarktinformatie en impact. ROA-TR2015/4, Maastricht University.

Fouarge, D., Kriechel, B., \& Dohmen, T. (2014). Occupational sorting of school graduates: The role of economic preferences. Journal of Economic Behavior \& Organization, 106, 335-351.

Grip, A. de, Borghans, L., Smits, W. (1998). Future developments in the job level and domain of high-skilled workers. In: H. Heijke, L. Borghans (eds), Towards a Transparent Labour Market for Educational Decisions, Ashgate, Aldershot/Brookfield USA/Singapore/Sydney, 1998, pp. 21-56.

Grip, A. de, Jacobs, A. (1999). De doorstroom van het initieel onderwijs naar het niet-initieel onderwijs. ROA-W1999/3, Maastricht University.

Grip, A. de, Meijboom, P., Willems, E. (1995). Vacatures, werkgelegenheidsontwikkeling en de vraag naar nieuwkomers op de arbeidsmarkt, Tijdschrift voor Politieke Economie, 18, 36-57.

Huber (1973)

Kwaak, T. (2006). PRISMA-M: een bedrijfstakkenmodel voor de middellange termijn. EIM, Zoetermeer.

Mark, N. C., M. Ogaki, D. Sul (2005). Dynamic seemingly unrelated cointegration regressions. The Review of Economic Studies, 72, 797-820.

Ministerie van Onderwijs, Cultuur en Wetenschap (2015). Referentieraming 2015. Den Haag.

ROA (2015a). De arbeidsmarkt naar opleiding en beroep 2020. ROA-R-2015/6, Maastricht University.

ROA (2015b). Schoolverlaters tussen onderwijs en arbeidsmarkt 2014. ROA-R-2015/3, Maastricht University.

ROA (2015c). Beroepenindeling ROA-CBS 2014 (BRC 2014). ROA-TR-2015/5, Maastricht University.

ROA (2016). ROA opleidingsindeling 2015. ROA-TR-2016/3, Maastricht University.

ROA (2017a). De arbeidsmarkt naar opleiding en beroep tot 2022. ROA-R-2017/10, Maastricht University.

ROA (2017b). Schoolverlaters tussen onderwijs en arbeidsmarkt 2016. ROA-R-2017/7, Maastricht University.

Shah, C., Burke, G. (2001). Occupational replacement demand in Australia. International Journal of Manpower, 22, 648-663.

Swamy, P. (1970). Efficient inference in a random coefficient regression model. Econometrica, 38, 311-323.

UWV (2015). UWV Arbeidsmarktprognose 2015-2016. UWV, Amsterdam.

Wieling M., Grip, A. de, Willems, E. (1990). Een systematische kwalitatieve typering van arbeidsmarktinformatie. ROA-W-1990/8, Maastricht University.

Willems, E. (1999). Modelling replacement demand: a random coefficient approach. ROA-RM-1999/2E, Maastricht University.

Willems, E., Borghans, L., Grip, A. de (1997). Exit or no entry? Replacement demand and shrinking employment. ROA, Paper for the EALE conference, Aarhus, Denmark.

Willems, E., Grip, A. de (1993). Forecasting replacement demand by occcupation and education. International Journal of Forecasting, 9, 173-185. 


\section{Appendix A}

Tabel A.1 Grenzen kwalitatieve typering voor indicatoren en prognoses tot 2022

indeling

variabelen

erg laag t.o.v. laag

laag t.o.v. gemiddeld

gemiddeld t.o.v. hoog

hoog t.o.v. erg hoog opleidingstype opleidingstype

opleidingstype opleidingstype opleidingstype opleidingstype opleidingstype beroepsgroep beroepsgroep beroepsgroep beroepsgroep beroepsgroep beroepsgroep bedrijfssector bedrijfssector

indeling

opleidingstype

indeling

opleidingstype

beroepsgroep verwachte uitbreidingsvraag tot 2022, gemiddeld jaarlijks \% verwachte vervangingsvraag tot 2022 , gemiddeld jaarlijks \% verwachte baanopeningen tot 2022 , gemiddeld jaarlijks \% verwachte instroom tot 2022, gemiddeld jaarlijks \% conjunctuurgevoeligheid uitwijkmogelijkheden naar bedrijfssectoren (indicator) uitwijkmogelijkheden naar beroepsgroepen (indicator) verwachte uitbreidingsvraag tot 2022 , gemiddeld jaarlijks $\%$ verwachte vervangingsvraag tot 2022 , gemiddeld jaarlijks $\%$ verwachte baanopeningen tot 2022, gemiddeld jaarlijks \% conjunctuurgevoeligheid

uitwijkmogelijkheden naar bedrijfssectoren (indicator) substitutiemogelijkheden naar opleidingstypen (indicator) verwachte uitbreidingsvraag tot 2022 , gemiddeld jaarlijks \% conjunctuurgevoeligheid

variabelen

ITA toekomstige arbeidsmarktsituatie in 2022

variabelen

ITKP toekomstige knelpunten personeelsvoorziening in 2022

ITKB toekomstige knelpunten beroepsgroep in 2022

0,49
1,44
2,2
1,54
0,83
3,28
4,9
$-0,48$
1,34
1,71
0,62
1,43
6,28
$-0,27$
0,65

zeer goed t.o.v. goed

groot t.o.v. zeer groot

0,80
0,82

6,22

11,23

0,23

2,72

0,79

2,28

10,3

0,31

0,75

goed t.o.v. redelijk

enige t.o.v. groot
1,41

redelijk t.o.v. matig

vrijwel geen t.o.v

enige geen t.o.v. vrijwel geen

1,05

0,90 
De grenzen en typering in Tabel A.1 hebben betrekking op de gegevens in het ArbeidsmarktInformatieSysteem (AIS-online tot 2022, ROA, 2017).

Er worden vijf typeringen onderscheiden: erg laag, laag, gemiddeld, hoog en erg hoog. Bij de Indicator toekomstige kans op knelpunten in de personeelsvoorziening (ITKP) zijn dit: zeer groot, groot, enige, vrijwel geen, geen. Bij de toekomstige knelpunten in de personeelsvoorziening naar beroepsgroep (ITKB) worden de volgende typeringen onderscheiden: geen t.o.v. vrijwel geen, vrijwel geen t.o.v. enige, enige t.o.v. groot, groot t.o.v. zeer groot.

Met uitzondering van de ITKP en de ITKB zijn voor alle variabelen die in Tabel A.1 voorkomen de grenzen bepaald op basis van de zogenaamde kwantielenmethode (zie ook Wieling, De Grip en Willems, 1990). Bij de kwantielenmethode worden de grenzen zodanig bepaald dat $10 \%$ in de klasse erg laag valt, $20 \%$ in laag, $40 \%$ in gemiddeld, $20 \%$ in hoog en $10 \%$ in de klasse erg hoog.

Voor de grenzen voor de ITKB is de procentuele verdeling van de beroepsgroepen bepaald aan de hand van de procentuele verdeling die voor de opleidingstypen van de ITKP gelden. Deze verdeling is opgelegd aan de knelpunten naar beroep. Als bijvoorbeeld $34 \%$ van de opleidingstypen gekenmerkt wordt door zeer grote knelpunten, wordt de grens tussen grote en zeer grote knelpunten bij de ITKB zodanig vastgesteld dat $34 \%$ van de beroepsgroepen ook de typering 'zeer grote knelpunten' krijgt. 


\section{Appendix B. Technische toelichting op variabelen in het AIS}

Tabel B1. Technische toelichting op de variabelen over de actuele situatie op de arbeidsmarkt in het AIS, naar databron

\begin{tabular}{|c|c|}
\hline EBB 2015-2016 & \\
\hline werkenden & Minimaal 1 uur werkzaam en in de leeftijd 15-74 \\
\hline werkenden in arbeidsvolume & $\begin{array}{l}\text { Arbeidsvolume is het totaal aantal normaal gewerkte arbeidsuren gedeeld door } \\
40 .\end{array}$ \\
\hline vrouwen & Percentage op basis van de werkzame beroepsbevolking. \\
\hline niet-westerse allochtonen & $\begin{array}{l}\text { Niet-westerse allochtonen, iedereen waarvan tenminste één ouder in het } \\
\text { buitenland is geboren, en waarvan de herkomst een niet westers land is. } \\
\text { Percentage op basis van de werkzame beroepsbevolking. }\end{array}$ \\
\hline gemiddelde leeftijd & Geen verdere toelichting. \\
\hline jongeren (15-29) & $\begin{array}{l}\text { De jongeren betreft alle mensen die ouder dan } 15 \text { jaar en jonger dan } 30 \text { jaar } \\
\text { zijn. Percentage op basis van de werkzame beroepsbevolking }\end{array}$ \\
\hline ouderen (55-74) & $\begin{array}{l}\text { De ouderen betreft alle mensen die ouder dan } 55 \text { jaar en jonger dan } 75 \text { jaar } \\
\text { zijn. Percentage op basis van de werkzame beroepsbevolking. }\end{array}$ \\
\hline vast dienstverband & $\begin{array}{l}\text { Personen met een vast dienstverband. Percentage op basis van werknemers in } \\
\text { de werkzame beroepsbevolking. }\end{array}$ \\
\hline flexibel werk & $\begin{array}{l}\text { Van een flexibele arbeidsrelatie is sprake bij uitzendkrachten, oproepkrachten, } \\
\text { invalskrachten en contracten zonder een vast aantal arbeidsuren en indien } \\
\text { geen vast dienstverband is overeengekomen. Percentage obv werknemers in } \\
\text { de werkzame beroepsbevolking. }\end{array}$ \\
\hline zelfstandig & $\begin{array}{l}\text { Het begrip zelfstandig bevat ook personen die werkzaam zijn in het bedrijf of de } \\
\text { praktijk van hun partner of ouders en freelancers e.d. Percentage op basis van } \\
\text { de werkzame beroepsbevolking. }\end{array}$ \\
\hline gemiddeld aantal uren werk per week & Geen verdere toelichting. \\
\hline deeltijd arbeid, minder dan 12 uur & $\begin{array}{l}\text { Deeltijdarbeid betreft personen die hoogstens } 12 \text { uur per week werkzaam zijn. } \\
\text { Percentage op basis van de werkzame beroepsbevolking. }\end{array}$ \\
\hline deeltijd arbeid, 12 tot 20 uur & $\begin{array}{l}\text { Deeltijdarbeid betreft personen die hoogstens } 20 \text { uur maar minstens } 12 \text { uur per } \\
\text { week werkzaam zijn. Percentage op basis van de werkzame beroepsbevolking. }\end{array}$ \\
\hline deeltijd arbeid, 20 tot 35 uur & $\begin{array}{l}\text { Deeltijdarbeid betreft personen die hoogstens } 35 \text { uur maar minstens } 20 \text { uur per } \\
\text { week werkzaam zijn. Percentage op basis van de werkzame beroepsbevolking. }\end{array}$ \\
\hline voltijd arbeid, 35 uur en meer & $\begin{array}{l}\text { Voltijdarbeid betreft personen die minstens } 35 \text { uur per week werkzaam zijn. } \\
\text { Percentage op basis van de werkzame beroepsbevolking. }\end{array}$ \\
\hline overwerk & Percentage van werkenden dat wel eens moet overwerken. \\
\hline ziekteverzuim in de afgelopen week & $\begin{array}{l}\text { Percentage van werkenden dat vorige week vanwege ziekte niet of minder } \\
\text { heeft gewerkt. }\end{array}$ \\
\hline midden- en kleinbedrijf & $\begin{array}{l}\text { Percentage van werkenden dat werkzaam is in een bedrijf met minder dan } 100 \\
\text { personen. }\end{array}$ \\
\hline trainingsintensiteit, $<6$ maanden & $\begin{array}{l}\text { Percentage van de werkenden die op het enquêtemoment een opleiding volgen } \\
\text { met een duur van minder dan } 6 \text { maanden. }\end{array}$ \\
\hline trainingsintensiteit, $>=6$ maanden & $\begin{array}{l}\text { Percentage van de werkenden die op het enquêtemoment een opleiding volgen } \\
\text { met een duur van } 6 \text { maanden of langer. }\end{array}$ \\
\hline student/scholier & Percentage van de werkenden met maatschappelijke positie student/scholier \\
\hline potentiële beroepsbevolking & $\begin{array}{l}\text { De potentiële beroepsbevolking betreft alle mensen die ouder zijn dan } 15 \text { en } \\
\text { jonger dan } 75 \text {, }\end{array}$ \\
\hline werkzame beroepsbevolking & $\begin{array}{l}\text { Het percentage werkzaam is de werkzame beroepsbevolking als percentage } \\
\text { van de potentiële beroepsbevolking. }\end{array}$ \\
\hline werkloze beroepsbevolking & Percentage personen die geen betaald werk hebben, wel recent hebben \\
\hline
\end{tabular}




\begin{tabular}{|c|c|}
\hline & $\begin{array}{l}\text { gezocht en daarvoor direct beschikbaar zijn als percentage van de potentiële } \\
\text { beroepsbevolking. }\end{array}$ \\
\hline beschikbare niet-beroepsbevolking & $\begin{array}{l}\text { Beschikbaar zijn alle personen in de niet-beroepsbevolking die binnen drie } \\
\text { maanden in een nieuwe werkkring kunnen beginnen. Percentage van de } \\
\text { potentiële beroepsbevolking. }\end{array}$ \\
\hline niet beschikbare niet-beroepsbevolking & $\begin{array}{l}\text { Niet-beschikbaar zijn alle personen in de niet-beroepsbevolking die niet binnen } \\
\text { drie maanden in een nieuwe werkkring kunnen beginnen. Percentage van de } \\
\text { potentiële beroepsbevolking. }\end{array}$ \\
\hline gemiddeld bruto uurloon (SSB2016) & $\begin{array}{l}\text { Gemiddeld bruto uurloon van werknemers in } 2016 \text { in euro's. Enquête } \\
\text { Beroepsbevolking (2016) gekoppeld aan het Sociaal Statistisch Bestand (SSB) } \\
2016 .\end{array}$ \\
\hline loonrisico, aantal euro per uur & Standaarddeviatie van bruto uurloon \\
\hline opleidingsachtergrond basisonderwijs & Geen verdere toelichting. \\
\hline opleidingsachtergrond vmbo & Geen verdere toelichting. \\
\hline opleidingsachtergrond vmbo $\mathrm{tl} / \mathrm{gl}$ & Geen verdere toelichting. \\
\hline opleidingsachtergrond havo/vwo & Geen verdere toelichting. \\
\hline opleidingsachtergrond mbo $2 / 3$ & Geen verdere toelichting. \\
\hline opleidingsachtergrond mbo 4 & Geen verdere toelichting. \\
\hline opleidingsachtergrond hbo & Geen verdere toelichting. \\
\hline opleidingsachtergrond wo & Geen verdere toelichting. \\
\hline belangrijkste beroep per opleiding & Geen verdere toelichting \\
\hline belangrijkste sector per opleiding & Geen verdere toelichting \\
\hline belangrijkste opleiding per beroep & Geen verdere toelichting \\
\hline belangrijkste sector per beroep & Geen verdere toelichting \\
\hline belangrijkste opleiding per sector & Geen verdere toelichting \\
\hline belangrijkste beroep per sector & Geen verdere toelichting \\
\hline \multicolumn{2}{|l|}{ bron: SIS 2016} \\
\hline participatie in vervolgopleiding, studie & $\begin{array}{l}\text { Percentage van alle schoolverlaters die een vervolgopleiding zijn gaan volgen. } \\
\text { Op basis van de maatschappelijke positie, ofwel de eigen interpretatie van de } \\
\text { belangrijkste bezigheid op het enquêtemoment. }\end{array}$ \\
\hline participatie in vervolgopleiding, BBL & $\begin{array}{l}\text { Percentage van alle schoolverlaters die een BBL vervolgopleiding zijn gaan } \\
\text { volgen. Op basis van de maatschappelijke positie, ofwel de eigen interpretatie } \\
\text { van de belangrijkste bezigheid op dit moment. }\end{array}$ \\
\hline werkloosheid & $\begin{array}{l}\text { Percentage gemeten in procenten van de schoolverlaters die behoren tot de } \\
\text { beroepsbevolking. }\end{array}$ \\
\hline $\begin{array}{l}\text { intredewerkloosheid van } 4 \text { maanden of } \\
\text { langer }\end{array}$ & $\begin{array}{l}\text { Intredewerkloosheid is gemeten onder werkzame schoolverlaters en betekent } \\
\text { het totaal aantal maanden dat dat schoolverlaters sinds het verlaten van de } \\
\text { opleiding als werkloos hebben opgegeven. }\end{array}$ \\
\hline vast dienstverband & Betreft schoolverlaters met een vast dienstverband. \\
\hline flexibel werk & $\begin{array}{l}\text { Uitzend-/oproepkrachten of andere soorten dienstverband (bv loondienst } \\
\text { meewerkend in bedrijf ouders/partner) met een tijdelijke aanstelling. }\end{array}$ \\
\hline deeltijd arbeid, minder dan 12 uur & Betreft de schoolverlaters die hoogstens 12 uur per week werkzaam zijn. \\
\hline deeltijd arbeid, 12 tot 20 uur & $\begin{array}{l}\text { Betreft de schoolverlaters die hoogstens } 20 \text { uur maar minstens } 12 \text { uur per week } \\
\text { werkzaam zijn. }\end{array}$ \\
\hline deeltijd arbeid, 20 tot 35 uur & $\begin{array}{l}\text { Betreft de schoolverlaters die hoogstens } 35 \text { uur maar minstens } 20 \text { uur per week } \\
\text { werkzaam zijn. }\end{array}$ \\
\hline voltijd arbeid, 35 uur en meer & Betreft de schoolverlaters die minstens 35 uur per week werkzaam zijn. \\
\hline gemiddelde leeftijd & $\begin{array}{l}\text { Leeftijd van schoolverlaters (incl. BBL) op het enquêtemoment, i.e. anderhalf } \\
\text { jaar na afstuderen. }\end{array}$ \\
\hline
\end{tabular}




\begin{tabular}{|c|c|}
\hline buiten de vakrichting & $\begin{array}{l}\text { Er is sprake van een functie buiten de eigen vakrichting als voor de functie de } \\
\text { eigen of verwante opleidingsrichting niet vereist is. }\end{array}$ \\
\hline onderbenutting & $\begin{array}{l}\text { Onderbenutting wordt bepaald op basis van het opleidingsniveau dat vereist is } \\
\text { voor de functie. }\end{array}$ \\
\hline spijt van de gevolgde opleiding & $\begin{array}{l}\text { Spijt over gevolgde opleiding. Er is gevraagd of men achteraf gezien dezelfde } \\
\text { opleiding zou kiezen. }\end{array}$ \\
\hline gemiddeld bruto maandloon & Bruto maandloon op basis van een voltijdaanstelling. \\
\hline gemiddeld aantal uren per week & Geen verdere toelichting. \\
\hline midden- en klein bedrijf & Midden- en kleinbedrijf, bedrijven waar tot 100 personen werkzaam zijn. \\
\hline niet-westerse allochtonen & $\begin{array}{l}\text { Niet-westerse allochtonen, iedereen waarvan tenminste één ouder in het } \\
\text { buitenland is geboren, en waarvan de herkomst een niet westers land is. }\end{array}$ \\
\hline \multicolumn{2}{|l|}{ bron: DUO 2016} \\
\hline leerlingen & $\begin{array}{l}\text { Aantal leerlingen in het jaar } 2016 \text { heeft betrekking op de leerlingen van } \\
\text { schooljaar 2016-2017. }\end{array}$ \\
\hline leerlingen - vrouw & $\begin{array}{l}\text { Percentage vrouwelijke leerlingen in jaar } 2016 \text { heeft betrekking op de } \\
\text { vrouwelijke leerlingen van schooljaar } 2016-2017 .\end{array}$ \\
\hline leerlingen - BBL & $\begin{array}{l}\text { Percentage BBL-leerlingen in jaar } 2016 \text { heeft betrekking op de leerlingen in de } \\
\text { beroepsbegeleidende leerweg van schooljaar 2016-2017. }\end{array}$ \\
\hline $\begin{array}{l}\text { leerlingen - deeltijd/duaal in hoger } \\
\text { onderwijs }\end{array}$ & $\begin{array}{l}\text { Percentage deeltijd/duaal leerlingen in jaar } 2016 \text { heeft betrekking op de } \\
\text { leerlingen in een deeltijd of duaal opleiding van schooljaar 2016-2017. }\end{array}$ \\
\hline gediplomeerden & $\begin{array}{l}\text { Aantal gediplomeerden in het jaar } 2016 \text { heeft betrekking op de gediplomeerden } \\
\text { van schooljaar } 2015-2016 \text {. }\end{array}$ \\
\hline gediplomeerden - vrouw & $\begin{array}{l}\text { Percentage vrouwelijke gediplomeerden in jaar } 2016 \text { heeft betrekking op de } \\
\text { vrouwelijke gediplomeerden van schooljaar } 2015-2016 \text {. }\end{array}$ \\
\hline gediplomeerden - BBL & $\begin{array}{l}\text { Percentage BBL-gediplomeerden in jaar } 2016 \text { heeft betrekking op de } \\
\text { gediplomeerden in de beroepsbegeleidende leerweg van schooljaar 2015-2016. }\end{array}$ \\
\hline $\begin{array}{l}\text { gediplomeerden - deeltijd/duaal in hoger } \\
\text { onderwijs }\end{array}$ & $\begin{array}{l}\text { Percentage deeltijd/duaal gediplomeerden in jaar } 2016 \text { heeft betrekking op de } \\
\text { gediplomeerden in een deeltijd of duaal opleiding van schooljaar 2015-2016. }\end{array}$ \\
\hline \multicolumn{2}{|l|}{$\begin{array}{l}\text { bron: SCP Arbeidsvraagpanel 2015- } \\
2016\end{array}$} \\
\hline vacatures & $\begin{array}{l}\text { Percentage vacatures op het enquêtemoment, op basis van } \\
\text { werknemersomvang. }\end{array}$ \\
\hline bedrijven met vacatures & $\begin{array}{l}\text { Percentage bedrijven met vacatures op het enquêtemoment, op basis van het } \\
\text { aantal bedrijven. }\end{array}$ \\
\hline $\begin{array}{l}\text { bedrijven met vacatures - langer dan } 3 \\
\text { maanden open }\end{array}$ & $\begin{array}{l}\text { Percentage bedrijven met vacatures die langer dan } 3 \text { maanden open staan, op } \\
\text { basis van het aantal bedrijven met vacatures. }\end{array}$ \\
\hline $\begin{array}{l}\text { bedrijven met vacatures - moeilijk } \\
\text { vervulbaar }\end{array}$ & $\begin{array}{l}\text { Percentage bedrijven met vacatures die moeilijk vervulbaar zijn, op basis van } \\
\text { het aantal bedrijven met vacatures. }\end{array}$ \\
\hline \multicolumn{2}{|l|}{ bron: SCP Arbeidsaanbodpanel 2016} \\
\hline $\begin{array}{l}\text { stank, lawaai, tocht of hoge/lage } \\
\text { temperaturen }\end{array}$ & Geen verdere toelichting \\
\hline werken met gevaarlijke stoffen & Geen verdere toelichting \\
\hline $\begin{array}{l}\text { werken onder gevaarlijke } \\
\text { omstandigheden }\end{array}$ & Geen verdere toelichting \\
\hline lichamelijk zwaar werk & Geen verdere toelichting \\
\hline geestelijk zwaar werk & Geen verdere toelichting \\
\hline emotioneel zwaar werk & Geen verdere toelichting \\
\hline agressie op de werkplek & Geen verdere toelichting \\
\hline $\begin{array}{l}\text { herhaling van dezelfde eenvoudige } \\
\text { werkzaamheden }\end{array}$ & Geen verdere toelichting \\
\hline werken met mensen (patiënten, cliënten, & Geen verdere toelichting \\
\hline
\end{tabular}




\begin{tabular}{|l|l|}
\hline enz.) & \\
\hline werk buiten mijn vak of beroep & Geen verdere toelichting \\
\hline zelf begintijd of eindtijd bepalen & Geen verdere toelichting \\
\hline $\begin{array}{l}\text { werk in ploegendienst of wisselende } \\
\text { diensten }\end{array}$ & Geen verdere toelichting \\
\hline werk met onregelmatige werktijden & Geen verdere toelichting \\
\hline werken in nachtdienst & Geen verdere toelichting \\
\hline werken op zaterdag & Geen verdere toelichting \\
\hline werken op zondag & Geen verdere toelichting \\
\hline $\begin{array}{l}\text { zelf bepalen waar u werkt (thuis, bij } \\
\text { werkgever, of elders) }\end{array}$ & Geen verdere toelichting \\
\hline bron: PIAAC 2014 & \begin{tabular}{l} 
Percentage werkenden dat aangeeft een computer op het werk te gebruiken \\
\hline gebruikt computer op het werk
\end{tabular} \\
\hline taalvaardigheid & $\begin{array}{l}\text { met vermogen om te lezen en begrijpen van geschreven teksten, maar ook om } \\
\text { nodig zijn om de betekenis van een geschreven tekst te kunnen achterhalen. }\end{array}$ \\
\hline rekenvaardigheid & $\begin{array}{l}\text { Het vermogen om mathematische informatie en ideeën te herkennen, te } \\
\text { gebruiken, te interpreteren en te communiceren, om op die manier op adequate } \\
\text { wijze om te gaan met de wiskundige eisen in een reeks van situaties in het } \\
\text { dagelijks leven. }\end{array}$ \\
\hline
\end{tabular}

Bron: ROA/POA 
Tabel B2. Technische toelichting op de variabelen uit de ROA arbeidsmarktprognoses in het AIS

\begin{tabular}{|c|c|}
\hline $\begin{array}{l}\text { verwachte } \\
\text { uitbreidingsvraag tot } \\
2022\end{array}$ & $\begin{array}{l}\text { Vraag naar nieuwe arbeidskrachten die ontstaat door groei van de werkgelegenheid. } \\
\text { Als er sprake is van een werkgelegenheidsdaling, is de uitbreidingsvraag negatief. }\end{array}$ \\
\hline $\begin{array}{l}\text { verwachte } \\
\text { vervangingsvraag tot } \\
2022\end{array}$ & $\begin{array}{l}\text { Vervangingsvraag is de vraag naar nieuwe arbeidskrachten die ontstaat door } \\
\text { bijvoorbeeld pensionering, (tijdelijke) uittreding vanwege zorgtaken, } \\
\text { arbeidsongeschiktheid, beroepsmobiliteit of doorstroom naar andere opleiding. }\end{array}$ \\
\hline $\begin{array}{l}\text { verwachte } \\
\text { baanopeningen tot } 2022\end{array}$ & $\begin{array}{l}\text { Baanopeningen zijn de totale vraag naar nieuwkomers op de arbeidsmarkt, zoals deze } \\
\text { is bepaald door de werkgelegenheidsgroei (positieve uitbreidingsvraag) en de } \\
\text { vervangingsvraag. }\end{array}$ \\
\hline $\begin{array}{l}\text { verwachte instroom van } \\
\text { schoolverlaters tot } 2022\end{array}$ & $\begin{array}{l}\text { De instroom is het verwachte aanbod van nieuwe arbeidskrachten op de arbeidsmarkt. } \\
\text { Deze is gebaseerd op de verwachte uitstroom van schoolverlaters uit het initiële dag-, } \\
\text { deeltijd-, niet-reguliere voltijdonderwijs en de beroepsgerichte volwasseneneducatie. }\end{array}$ \\
\hline $\begin{array}{l}\text { ITKB toekomstige } \\
\text { knelpunten } \\
\text { beroepsgroep in } 2022\end{array}$ & $\begin{array}{l}\text { Indicator Toekomstige Knelpunten naar Beroepsgroepen (ITKB) in } 2022 \text {. Naarmate de } \\
\text { waarde van de indicator lager wordt, zijn de verwachte knelpunten groter. }\end{array}$ \\
\hline $\begin{array}{l}\text { ITKP toekomstige } \\
\text { knelpunten } \\
\text { personeelsvoorziening in } \\
2022\end{array}$ & $\begin{array}{l}\text { Indicator Toekomstige Knelpunten in de Personeelsvoorziening (ITKP) in } 2022 . \\
\text { Naarmate de waarde van de indicator lager wordt, zijn de verwachte knelpunten in de } \\
\text { personeelsvoorziening groter. }\end{array}$ \\
\hline $\begin{array}{l}\text { ITA toekomstige } \\
\text { arbeidsmarktsituatie in } \\
2022\end{array}$ & $\begin{array}{l}\text { Indicator Toekomstige Arbeidsmarktsituatie (ITA) in 2022. Naarmate de waarde van ITA } \\
\text { hoger ligt, is er sprake van een slechter arbeidsmarktperspectief. Een waarde tussen } \\
1,01 \text { en } 1,05 \text { duidt op een evenwichtssituatie. }\end{array}$ \\
\hline $\begin{array}{l}\text { instroom met ITA } \\
\text { goed/zeer goed }\end{array}$ & $\begin{array}{l}\text { Percentage van de instroom in de onderliggende opleidingstypes waarvoor een goed } \\
\text { tot zeer goed arbeidsmarktperspectief wordt verwacht }\end{array}$ \\
\hline $\begin{array}{l}\text { instroom met ITA } \\
\text { slecht/matig }\end{array}$ & $\begin{array}{l}\text { Percentage van de instroom in de onderliggende opleidingstypes waarvoor een matig } \\
\text { tot slecht arbeidsmarktperspectief wordt verwacht }\end{array}$ \\
\hline $\begin{array}{l}\text { Knelpunten in de } \\
\text { personeelsvoorziening } \\
\text { naar bedrijfssector in } \\
2022\end{array}$ & $\begin{array}{l}\text { In de verwachte knelpunten opleiding zijn de opleidingstypen alleen opgenomen } \\
\text { wanneer meer dan } 5 \% \text { van de werkenden met deze opleidingsachtergrond emplooi } \\
\text { vindt in de betreffende bedrijfssector. }\end{array}$ \\
\hline $\begin{array}{l}\text { Knelpunten in de } \\
\text { beroepsgroepen naar } \\
\text { bedrijfssector in } 2022\end{array}$ & $\begin{array}{l}\text { In de verwachte knelpunten beroep zijn de beroepsgroepen alleen opgenomen } \\
\text { wanneer meer dan } 5 \% \text { van de werkenden met deze beroepsachtergrond emplooi vindt } \\
\text { in de betreffende bedrijfssector. }\end{array}$ \\
\hline
\end{tabular}

Bron: ROA/POA 
Tabel B3. Technische toelichting op de risico-indicatoren in het AIS

\begin{tabular}{|c|c|}
\hline loopbaanperspectief & $\begin{array}{l}\text { Bruto uurloon van werkenden in de leeftijdsgroep } 40-49 \text { jaar ten opzichten van bruto } \\
\text { uurloon van werkenden in de leeftijdsgroep } 20-29 \text { jaar }\end{array}$ \\
\hline $\begin{array}{l}\text { uitwijkmogelijkheden } \\
\text { naar beroepsgroep }\end{array}$ & $\begin{array}{l}\text { Deze maatstaf geeft aan in hoeverre arbeidskrachten afhankelijk zijn van de } \\
\text { arbeidsmarktsituatie in een bepaalde beroepsgroep, een genormeerd aantal } \\
\text { beroepsgroepen waarin mensen met dit opleidingstype werkzaam zijn. }\end{array}$ \\
\hline $\begin{array}{l}\text { uitwijkmogelijkheden } \\
\text { naar sector }\end{array}$ & $\begin{array}{l}\text { Deze maatstaf geeft aan in hoeverre arbeidskrachten afhankelijk zijn van de } \\
\text { arbeidsmarktsituatie in een bepaalde bedrijfssector, een genormeerd aantal } \\
\text { bedrijfssectoren waarin mensen met dit opleidingstype/beroepsgroep werkzaam } \\
\text { zijn. }\end{array}$ \\
\hline $\begin{array}{l}\text { substitutiemogelijkheden } \\
\text { naar opleidingstype }\end{array}$ & $\begin{array}{l}\text { Geeft de mate aan waarin werkgevers voor een bepaald beroep arbeidskrachten } \\
\text { kunnen aantrekken met een uiteenlopende opleidingsachtergrond. Een genormeerd } \\
\text { aantal opleidingstypen waaruit werkenden in deze beroepsgroep afkomstig zijn. }\end{array}$ \\
\hline conjunctuurgevoeligheid & $\begin{array}{l}\text { Maatstaf voor de mate waarin de werkgelegenheid gevoelig is voor veranderingen } \\
\text { van de economische situatie. }\end{array}$ \\
\hline concurrentieindex & $\begin{array}{l}\text { Index geeft aan hoe sterk de beroepenstructuur van twee opleidingen op elkaar lijkt, } \\
\text { dat wil zeggen hoe groot de kans is dat personen met verschillende } \\
\text { opleidingsachtergrond in dezelfde beroepsgroep werkzaam zijn }\end{array}$ \\
\hline
\end{tabular}

Bron: ROA/POA 